Article

\title{
Biochars Improve Nutrient Retention Capacity of Highly Weathered Tropical Soils
}

\author{
Arnoldus Klau Berek ${ }^{*}$, Nguyen V. Hue ${ }^{2}$, Theodore J. K. Radovich ${ }^{3}$, and Amjad A. Ahmad \\ 1 Program Studi Agroteknologi, Universitas Timor, Jl. Km 9, Kel. Sasi, Kec. Kota, Kefamenanu, TTU, NTT \\ 85613 Indonesia; b3r3kk14u@gmail.com \\ 2 Department of Tropical Plant and Soil Sciences, University of Hawaii at Manoa, St. John Plant Science Lab, \\ Room 1023190 Maile Way Honolulu, Hawaii 96822 USA; nvhue@hawaii.edu \\ 3 Department of Tropical Plant and Soil Sciences, University of Hawaii at Manoa, St. John Plant Science Lab, \\ Room 1023190 Maile Way Honolulu, Hawaii 96822 USA; theodore@hawaii.edu \\ 4 Department of Tropical Plant and Soil Sciences, University of Hawaii at Manoa, St. John Plant Science Lab, \\ Room 1023190 Maile Way Honolulu, Hawaii 96822 USA; alobady@hawaii.edu \\ * Correspondence: b3r3kkl4u@gmail.com; Tel.: +62-81339337111
}

\begin{abstract}
Highly weathered soils in the tropics are low in fertility, negatively affecting plant growth. The potential of biochar for improving soil nutrient retention is reportedly promising, triggering this study to assess the nutrient retention capacities of two biochars when applied at $2 \%$ in combination with two composts also applied at $2 \%$ to an Ultisol (Ustic Kanhaplohumult, Leilehua series) and an Oxisol (Rhodic haplustox, Wahiawa series) of Hawai'i. Chinese cabbage (Brassica rapa cv. Bonsai) was used as the test plant in two greenhouse plantings, which had a factorial completely randomized design with three replicates per treatment. The results indicated that the combined additions of biochar and compost significantly increased the $\mathrm{pH}, \mathrm{EC}, \mathrm{P}$ and $\mathrm{K}$ of the soils; improved $\mathrm{Ca}, \mathrm{Mg}$ and Fe uptake; and increased shoot and total cabbage fresh and dry matter. Exchangeable aluminum in the Ultisol was decreased from $2.5 \mathrm{cmol}+/ \mathrm{kg}$ to virtually zero. Extractable $\mathrm{Mn}$ and $\mathrm{Fe}$ in the high Mn-Oxisol were decreased by 55 and $42 \%$, respectively. Chinese cabbage growth in the Ultisol amended with the lac tree (Schleichera oleosa) wood biochar and vermicompost was almost twice over lime at $2 \mathrm{cmol}+/ \mathrm{kg}$. Essential nutrients in the plant tissues, with the exception of $\mathrm{N}$ and $\mathrm{K}$, were sufficient for the cabbage growth, suggesting increases in nutrients and reduced soil acidity by the additions of biochar combined with compost were the probable cause.
\end{abstract}

Keywords: biochar; compost; nutrient retention; highly weathered soil; Chinese cabbage.

\section{Introduction}

Highly weathered soils are poor in nutrients mainly because of leaching. Low soil fertility necessitates fertilizer applications which increase cost of crop production, and can result in environmental issues such as algal bloom and contamination of water bodies [1]. Biochar reportedly has good capacity to retain nutrients due to its numerous pores and large surface area/charge $[2,3]$. Recent research has shown that additions of biochar reduced nutrient losses from the agricultural lands [4-10). Other observed benefits such as increased soil water retention [11,12], raised soil $\mathrm{pH}$ [13] and cation exchange capacity (CEC) [14,15], improved beneficial soil microbial population and activities [16,17], and consequently, enhanced plant growth. More specifically, biochar can reduce nitrate, ammonium, phosphorus, and cation concentration in the soil leachate $[4,6,7,18]$. For example, addition of a mixed hardwood biochar at $20 \mathrm{~g} / \mathrm{kg}$ in combination with swine manure at 5 $\mathrm{g} / \mathrm{kg}$ to a typical agricultural soil (a Hapludoll) of the Midwestern USA reduced total $\mathrm{N}$ and total dissolved P leaching by $11 \%$ and $69 \%$, respectively, in a leaching column study [4]. Addition of biochars produced at higher temperature with large surface area may benefit sandy soils by 
increasing sorption sites and/or by improving the retention of nonpolar pollutant in soils and reducing nutrient leaching $[19,20]$.

The nutrient retention capacity of biochar could be attributed to its large surface area, porosity, and surface charge, organic coating, and other factors, such as $\mathrm{pH}$ and ionic competition [2,3,21]. For example, NH4-N adsorption is due to cation exchange of the surface functional (e.g. phenolic and carboxylic) groups of biochar produced at relatively low $\left(300-400^{\circ} \mathrm{C}\right)$ temperature [22] and physical entrapment in biochars pores [23]. In contrast, $\mathrm{NO}_{3}-\mathrm{N}$ adsorption on the basic functional groups can be increased by increasing pyrolysis temperature [22]. Immobilization of $\mathrm{N}$ by microorganisms was also observed in low temperature-produced biochar [24]. Phosphorus ions were specifically adsorbed at certain sites of biochar or precipitated by Ca [25]. However, it appears that some biochars have no or only little effect on nutrient retention, and the degree of retention depended on biochar types, soil properties and other environmental conditions. The objective of this study was to evaluate the nutrient regulation or enhancement role of two biochars applied in combination with two composts to two highly weathered, tropical soils as measured by the nutrient uptake and growth of Chinese cabbage (Brassica rapa).

\section{Materials and Methods}

The nutrient retention of biochars were studied in a greenhouse, at the Magoon research facility, University of Hawai'i at Manoa, Honolulu, Hawai'i, using two acid soils, an Ultisol (Ustic Kanhaplohumult, Leilehua series) and an Oxisol (Rhodic haplustox,Wahiawa series). Soil samples were air dried, crushed and screened to pass a $4 \mathrm{~mm}$ sieve for the pot experiment. Finer $(<0.5 \mathrm{~mm})$ soil particles were used in chemical analysis. Wood-based biochars collected from Indonesia and Hawai' $i$, were oven dried at $70^{\circ} \mathrm{C}$ for 48 hours, ground and sieved to pass a 60 mesh $(0.25 \mathrm{~mm})$ sieve and stored before use. Selected properties of the biochars are listed in Table 1. Surface structure and porosity of biochars were measured with a scanning electron microscope (SEM) (HITACHI; Hitachi High-technologies, Corp., Tokyo, Japan). Pore diameters were measured from 2,000-time magnified SEM images. The $\mathrm{pH}\left(\mathrm{H}_{2} \mathrm{O}\right)$ of soils, biochars and composts were measured with a $\mathrm{pH}$ meter in a mixture of soil, biochar, compost and deionized water of 1:1, 1:5 and 1:5, respectively. The EC of soil, biochars and composts were measured using a $\mathrm{pH} / \mathrm{EC}$ meter in a mixture of soil, biochar, compost and deionized water of 1:1, 1:5, and 1:10, respectively. The functional groups of biochar (carboxylic and phenolic) were quantified using the Boehm titration method [26]. Water soluble salts and carbonates in biochar were removed before the titration. Briefly, $0.50 \mathrm{~g}$ of fine biochar was added to $50 \mathrm{~mL}$ of each of the three $0.05 \mathrm{M}$ bases: $\mathrm{NaHCO}_{3}, \mathrm{Na}_{2} \mathrm{CO}_{3}$, and $\mathrm{NaOH}$. The mixtures, along with a control solution without biochar, was shaken for $24 \mathrm{~h}$ and then filtered to remove particles. Then, 5 $\mathrm{mL}$ of each filtrate were mixed with $10 \mathrm{~mL}$ of $0.05 \mathrm{M} \mathrm{HCl}$ and back-titrated with $0.05 \mathrm{M} \mathrm{NaOH}$. The endpoint was determined using a $\mathrm{pH}$ meter and phenolphthalein color indicator. The total surface acidity was calculated as the quantity neutralized by $\mathrm{NaOH}$, the carboxylic acid fraction as that neutralized by $\mathrm{NaHCO}_{3}$, and the lactonic fraction as that neutralized by $\mathrm{Na}_{2} \mathrm{CO}_{3}$. The difference between quantity of $\mathrm{NaOH}$ and $\mathrm{Na}_{2} \mathrm{CO}_{3}$ is assumed to be the phenolic group content [27].

A locally produced vermicompost and a commercial thermocompost were collected from Honolulu, Hawai'i, oven dried at $70^{\circ} \mathrm{C}$ for 72 hours, screened to pass a $0.5 \mathrm{~mm}$ sieve for chemical analysis. Nutrient content of the composts were determined with an Inductively Coupled Plasma (ICP) spectrometer after a $0.20 \mathrm{~g}$ sample was burned at $500^{\circ} \mathrm{C}$ for 4 hours. The ash was dissolved with $15 \mathrm{~mL}$ of $0.1 \mathrm{M} \mathrm{HCl}$. Soil exchangeable aluminum was measured with $1 \mathrm{M} \mathrm{KCl}$ leaching/titration method. The measured $\mathrm{pH}, \mathrm{EC}$ and nutrient content in the soils, biochars and composts are listed in Table 1. Hydrated lime (Bandini ${ }^{\circledR}$ ) with the $\mathrm{CaCO}_{3}$ equivalent of 108 was dried and screened through a 60 mesh sieve before use.

Table 1. Selected properties of soils, biochars and composts used in the experiment 
3 of 16

\begin{tabular}{|c|c|c|c|c|c|c|}
\hline Selected properties & $\begin{array}{l}\text { Leilehua } \\
\text { Ultisol }\end{array}$ & $\begin{array}{l}\text { Wahiawa } \\
\text { Oxisol }\end{array}$ & $\begin{array}{l}\text { Lactree } \\
\text { wood } \\
\text { biochar }\end{array}$ & $\begin{array}{l}\text { Hilo mixed } \\
\text { wood biochar }\end{array}$ & Vermicompost & Thermocompost \\
\hline $\mathrm{PH}\left(\mathrm{H}_{2} \mathrm{O}\right)$ & 4.5 & 5.6 & 9.2 & 9.5 & 7.2 & 8.3 \\
\hline $\mathrm{EC}(\mathrm{dS} / \mathrm{m})$ & $0.08 \pm 0.00$ & $0.13 \pm 0.00$ & $1.93 \pm 0.01$ & $2.42 \pm 0.01$ & $2.28 \pm 0.03$ & $3.23 \pm 0.02$ \\
\hline CEC ( $\left.\mathrm{cmol}_{+} / \mathrm{kg}\right)$ & $16.8 \pm 0.45$ & $12.1 \pm 0.23$ & $18.0 \pm 1.75$ & $14.7 \pm 0.20$ & $44.8 \pm 3.50$ & $44.5 \pm 1.00$ \\
\hline N (\%) & $0.21 \pm 0.00$ & $0.15 \pm 0.00$ & $0.40 \pm 0.02$ & $0.50 \pm 0.09$ & $1.42 \pm 00.0$ & $1.90 \pm 0.00$ \\
\hline $\mathrm{P}(\mathrm{mg} / \mathrm{kg})$ & $1.95 \pm 0.03$ & $51.52 \pm 0.08$ & $0.06 \pm 0.00$ & $0.09 \pm 0.00$ & $1.48 \pm 0.00$ & $0.17 \pm 0.01$ \\
\hline $\mathrm{K}(\mathrm{mg} / \mathrm{kg})$ & $49.15 \pm 0.53$ & $140.70 \pm 1.08$ & $0.33 \pm 0.00$ & $0.47 \pm 0.00$ & $0.04 \pm 0.00$ & $1.37 \pm 0.01$ \\
\hline $\mathrm{Ca}(\mathrm{mg} / \mathrm{kg})$ & $111.84 \pm 5.09$ & $715.88 \pm 5.68$ & $3.13 \pm 0.00$ & $1.6 \pm 0.01$ & $2.11 \pm 0.67$ & $2.39 \pm 0.05$ \\
\hline $\mathrm{Mg}(\mathrm{mg} / \mathrm{kg})$ & $53.93 \pm 1.06$ & $232.60 \pm 0.07$ & $0.13 \pm 0.00$ & $0.22 \pm 0.00$ & $0.36 \pm 0.00$ & $0.36 \pm 0.00$ \\
\hline $\mathrm{Fe}(\mathrm{mg} / \mathrm{kg})$ & $98.14 \pm 1.41$ & $63.95 \pm 0.59$ & $684 \pm 0.00$ & $12259.5 \pm 233.65$ & $2407.90 \pm 30.94$ & $8345.20 \pm 103.11$ \\
\hline $\mathrm{Mn}(\mathrm{mg} / \mathrm{kg})$ & $11.41 \pm 0.05$ & $805.80 \pm 5.35$ & $55 \pm 0.00$ & $153.8 \pm 2.32$ & $606.00 \pm 0.68$ & $239.20 \pm 1.23$ \\
\hline $\mathrm{Al}(\mathrm{mg} / \mathrm{kg})$ & $2517.53 \pm 5.48$ & $1503.76 \pm 12.67$ & $448.1 \pm 0.00$ & $9766.9 \pm 154.72$ & $1832.00 \pm 57.79$ & $9933.30 \pm 39.17$ \\
\hline $\begin{array}{l}\text { Exchangable Al } \\
(\mathrm{cmol}+\mathrm{kg})\end{array}$ & $2.16 \pm 0.02$ & $0.17 \pm 0.01$ & - & - & - & - \\
\hline $\begin{array}{l}\text { Total functional groups } \\
\text { (mmol/g) }\end{array}$ & - & - & $0.38 \pm 0.02$ & $0.58 \pm 0.03$ & - & - \\
\hline $\begin{array}{l}\text { Carboxylic functional } \\
\text { group }(\mathrm{mmol} / \mathrm{g})\end{array}$ & - & - & $0.12 \pm 0.02$ & $0.22 \pm 0.02$ & - & - \\
\hline $\begin{array}{l}\text { Phenolic functional } \\
\text { groups (mmol/g) }\end{array}$ & - & - & $0.20 \pm 0.04$ & $0.27 \pm 0.03$ & - & - \\
\hline $\begin{array}{l}\text { Lactonic functional } \\
\text { group }(\mathrm{mmol} / \mathrm{g})\end{array}$ & - & - & $0.07 \pm 0.02$ & $0.10 \pm 0.03$ & - & - \\
\hline
\end{tabular}

The treatments, consisting of soil, biochar and compost, were arranged in a $2 \times 2 \times 2$ factorial completely randomized design with 3 replicates, and a $2 \mathrm{cmol}+/ \mathrm{kg}$ lime treatment was included for comparison. Two biochars, namely lac tree (Schleichera oleosa) wood and Hilo mixed wood, were applied at 0 (control) and $2 \%(\mathrm{w} / \mathrm{w})$. The compost treatments were 0 and $2 \%(\mathrm{w} / \mathrm{w})$. After three weeks of incubation, all pots $(1 \mathrm{~kg}$ soil/pot) were planted with Chinese cabbage (Brassica rapa) cv. Bonsai Chinensis group, which was harvested after 34 days of growth. The cabbage planting was repeated once (second planting). Shoots and roots were carefully removed from the soil, washed, and the fresh weight was measured before oven-drying at $70^{\circ} \mathrm{C}$ for 48 hours. Soil samples were collected from each pot at 16 days after addition of biochar and compost (a week before the first planting) and 52 days (a week after harvest of the first planting), air-dried, crushed, and passed through a $0.5 \mathrm{~mm}$ sieve before analysis. Soil $\mathrm{pH}$ and $\mathrm{EC}$ were measured using a $\mathrm{pH}$ meter in a 1:1 mixture of soil and deionized water. Total carbon and nitrogen content was measured by dry combustion in a LECO CN-2000 elemental analyzer (Leco Corp., St. Joseph, MI). Soil nutrients quantified with an ICP Spectrometer after extraction with the Mehlich 3 solution [28]. Dry weights of shoots and roots were recorded. Plant nutrients were quantified with an ICP Spectrometer after dry digested and dissolved in $0.1 \mathrm{M} \mathrm{HCl}$.

\subsection{Statistical Analysis}

Means and standard errors were calculated using a descriptive analysis from two or three replicates of the measured soil $\mathrm{pH}$, electrical conductivity, plant dry weight, and nutrient content in soils and plant tissues. The relationship between nutrient uptake and plant dry matter was analyzed using regression analysis in Microsoft Excel 2010 (Microsoft Corp., Redmond, WA). Histogram figures of soil aluminum changes and plant growth differences resulting from the biochar application were drawn using Microsoft Excel 2010 software. The effect of treatments on soil properties and cabbage growth were analyzed by a two-way analysis of variance using PROC ANOVA GLM of the SAS 9.2 software, and Tukey tests at $\mathrm{P} \leq 0.05$ were performed to test the significant differences. 
4 of 16

\section{Results}

\subsection{Soil $p H, E C$ and Exchangeable $A l$}

The soil pH significantly increased from 4.5 to 5.9 in the Ultisol and from 5.6 to 6.9 in the Oxisol, two weeks after treated with biochars in combination with composts (Table 2). They were further increased to 6.5 (Ultisol) and 7.2 (Oxisol), 7 weeks after treatment applications. The $\mathrm{pH}$ increase of the Ultisol at two weeks after treatment was significantly affected by the interaction of biochar and compost $(\mathrm{P}<0.01)$; however, the $\mathrm{pH}$ increases at 7 weeks were due to the effect of compost or biochar alone $(\mathrm{P}<0.001)$. Among the treatments, vermicompost in combination with either biochar increased $\mathrm{pH}$ the most. The $\mathrm{pH}$ increases in the Oxisol in both sampling times were affected by the interaction of biochar and compost $(\mathrm{P}<0.05)$. The data strongly demonstrate the liming capacity of both biochar and compost, especially for low $\mathrm{pH}$ soils. For comparison, the lime treatment raised soil $\mathrm{pH}$ to 5.6 and 6.8 in the Ultisol and Oxisol, respectively, two weeks after treated.

Table 2. Means and standard errors pH and EC of Leilehua Ultisol 2 and 7 weeks after being incubated with biochars and composts $(\mathrm{n}=3)$

\begin{tabular}{|c|c|c|c|c|}
\hline Treatments & pH 2 weeks & pH 7 weeks & EC 2 weeks & $\mathrm{d} S / \mathrm{m}$ \\
\hline \multicolumn{5}{|l|}{ Ultisol soil } \\
\hline Lac tree wood biochar $2 \%$ & $5.8 \pm 0.07 \mathrm{bc}$ & $5.8 \pm 0.22 \mathrm{de}$ & $0.20 \pm 0.01 \mathrm{~d}$ & $0.26 \pm 0.02 \mathrm{c}$ \\
\hline Hilo mixed wood biochar $2 \%$ & $4.8 \pm 0.01 \mathrm{e}$ & $4.8 \pm 0.07 \mathrm{~g}$ & $0.22 \pm 0.00 \mathrm{~d}$ & $0.25 \pm 0.01 \mathrm{c}$ \\
\hline Vermicompost $2 \%$ & $5.7 \pm 0.02 \mathrm{c}$ & $6.3 \pm 0.07 \mathrm{bc}$ & $0.51 \pm 0.01 \mathrm{ab}$ & $0.38 \pm 0.01 \mathrm{a}$ \\
\hline Thermocompost $2 \%$ & $5.1 \pm 0.03 \mathrm{e}$ & $5.5 \pm 0.09 \mathrm{f}$ & $0.39 \pm 0.02 \mathrm{c}$ & $0.27 \pm 0.02 c$ \\
\hline Lac tree wood $2 \%+$ vermicompost $2 \%$ & $5.9 \pm 0.04 \mathrm{ab}$ & $6.5 \pm 0.71 \mathrm{ab}$ & $0.51 \pm 0.04 \mathrm{ab}$ & $0.38 \pm 0.01 \mathrm{a}$ \\
\hline Lac tree wood $2 \%+$ thermocompost $2 \%$ & $5.8 \pm 0.08 \mathrm{bc}$ & $6.1 \pm 0.04 \mathrm{~cd}$ & $0.43 \pm 0.02 \mathrm{bc}$ & $0.29 \pm 0.01 \mathrm{bc}$ \\
\hline Hilo mixed wood $2 \%+$ vermicompost $2 \%$ & $5.8 \pm 0.02 \mathrm{bc}$ & $6.5 \pm 0.02 \mathrm{ab}$ & $0.55 \pm 0.02 \mathrm{a}$ & $0.36 \pm 0.02 \mathrm{ab}$ \\
\hline Hilo mixed wood $2 \%+$ thermocompost $2 \%$ & $5.4 \pm 0.01 \mathrm{~d}$ & $5.8 \pm 0.11 \mathrm{de}$ & $0.46 \pm 0.02 \mathrm{abc}$ & $0.29 \pm 0.03 b c$ \\
\hline Lime $2 \mathrm{cmol}_{+} / \mathrm{kg}+$ vermicompost $2 \%$ & $6.1 \pm 0.03 \mathrm{a}$ & $6.6 \pm 0.07 \mathrm{a}$ & $0.50 \pm 0.02 \mathrm{ab}$ & $0.38 \pm 0.03 \mathrm{a}$ \\
\hline Lime $2 \mathrm{cmol}+/ \mathrm{kg}+$ thermocompost $2 \%$ & $5.6 \pm 0.03 c$ & $6.1 \pm 0.07 \mathrm{~cd}$ & $0.47 \pm 0.01 \mathrm{abc}$ & $0.25 \pm 0.01 \mathrm{c}$ \\
\hline \multicolumn{5}{|l|}{ Oxisol soil } \\
\hline Lac tree wood biochar $2 \%$ & $6.5 \pm 0.03 b$ & $6.6 \pm 0.09 \mathrm{~d}$ & $0.27 \pm 0.00 \mathrm{e}$ & $0.34 \pm 0.01 \mathrm{~b}$ \\
\hline Hilo mixed wood biochar $2 \%$ & $6.0 \pm 0.03 \mathrm{~d}$ & $6.0 \pm 0.08 \mathrm{e}$ & $0.26 \pm 0.01 \mathrm{e}$ & $0.35 \pm 0.04 \mathrm{~b}$ \\
\hline Vermicompost $2 \%$ & $6.4 \pm 0.11 \mathrm{~cd}$ & $6.9 \pm 0.09 \mathrm{bc}$ & $0.47 \pm 0.02 \mathrm{bcd}$ & $0.42 \pm 0.02 \mathrm{ab}$ \\
\hline Thermocompost $2 \%$ & $6.3 \pm 0.16 \mathrm{~cd}$ & $6.5 \pm 0.03 \mathrm{~d}$ & $0.47 \pm 0.01 \mathrm{bcd}$ & $0.49 \pm 0.03 \mathrm{a}$ \\
\hline Lac tree wood $2 \%+$ vermicompost $2 \%$ & $6.8 \pm 0.05 \mathrm{ab}$ & $7.2 \pm 0.09 \mathrm{ab}$ & $0.43 \pm 0.00 \mathrm{~d}$ & $0.40 \pm 0.02 \mathrm{ab}$ \\
\hline Lac tree wood $2 \%+$ thermocompost $2 \%$ & $6.7 \pm 0.09 \mathrm{abc}$ & $7.1 \pm 0.12 \mathrm{abc}$ & $0.46 \pm 0.01 \mathrm{bcd}$ & $0.46 \pm 0.01 \mathrm{a}$ \\
\hline Hilo mixed wood $2 \%$ + vermicompost $2 \%$ & $6.9 \pm 0.09 \mathrm{ab}$ & $7.2 \pm 0.03 \mathrm{ab}$ & $0.49 \pm 0.00 \mathrm{bc}$ & $0.44 \pm 0.01 \mathrm{ab}$ \\
\hline Hilo mixed wood $2 \%+$ thermocompost $2 \%$ & $6.3 \pm 0.02 \mathrm{~cd}$ & $6.8 \pm 0.01 \mathrm{bcd}$ & $0.58 \pm 0.02 \mathrm{a}$ & $0.44 \pm 0.03 \mathrm{ab}$ \\
\hline Lime $2 \mathrm{cmol}+/ \mathrm{kg}+$ vermicompost $2 \%$ & $7.1 \pm 0.02 \mathrm{a}$ & $7.3 \pm 0.01 \mathrm{a}$ & $0.45 \pm 0.01 \mathrm{~cd}$ & $0.44 \pm 0.01 \mathrm{ab}$ \\
\hline Lime $2 \mathrm{cmol}+/ \mathrm{kg}+$ thermocompost $2 \%$ & $6.8 \pm 0.08 \mathrm{ab}$ & $7.1 \pm 0.02 \mathrm{abc}$ & $0.52 \pm 0.01 \mathrm{ab}$ & $0.41 \pm 0.02 \mathrm{ab}$ \\
\hline
\end{tabular}

Means within a column followed by the same letter(s) were not significantly different by Tukey's test at $\alpha=5 \%$.

Soil EC increased after 2 weeks of incubation and then decreased after the first harvest (Table 2). It increased from 0.35 to $0.47 \mathrm{dS} / \mathrm{m}$ (Ultisol) and from 0.30 to $0.37 \mathrm{dS} / \mathrm{m}$ (Oxisol). It then, however, decreased after the first harvest particularly in the Ultisol soil perhaps due to the removal of nutrients from the soil by cabbage plants. The increased EC in the Ultisol was significantly affected by compost alone, while the increased EC of the Oxisol 2 weeks after treatment was affected by the interaction of biochar and compost $(\mathrm{P}<0.01)$. Further increases of soil EC after 2 weeks of incubation were attributed to the compost alone. Such soil EC increases were attributed mainly to the basic cations (K, Ca, Mg) enrichment by both biochar and compost in the Oxisol and mostly by compost in the Ultisol (Tables 3a-b).

Soil exchangeable $\mathrm{Al}$ of acid Ultisol was reduced from $2.16 \mathrm{cmol}+/ \mathrm{kg}$ to 1.27 and $0.17 \mathrm{cmol}+/ \mathrm{kg}$ by the additions of the Hilo mixed wood and Lac tree biochars alone, respectively. Thermo-compost and Vermi-compost reduced the exchangeable Al to $0.14 \mathrm{cmol}+/ \mathrm{kg}$ and undetected level, respectively. Combination of biochars and compost eliminated the exchangeable $\mathrm{Al}$ to undetected level (Fig. 1a). Exchangeable Al in the Oxisol was reduced from $0.12 \mathrm{cmol}+/ \mathrm{kg}$ to undetectable level 
by additions of biochars or composts alone at $2 \%$ or in combination of both (Fig. 1b). For comparison, lime at $2 \mathrm{cmol}+/ \mathrm{kg}$ in combination with composts reduced exchangeable $\mathrm{Al}$ to undetectable level in both soils.

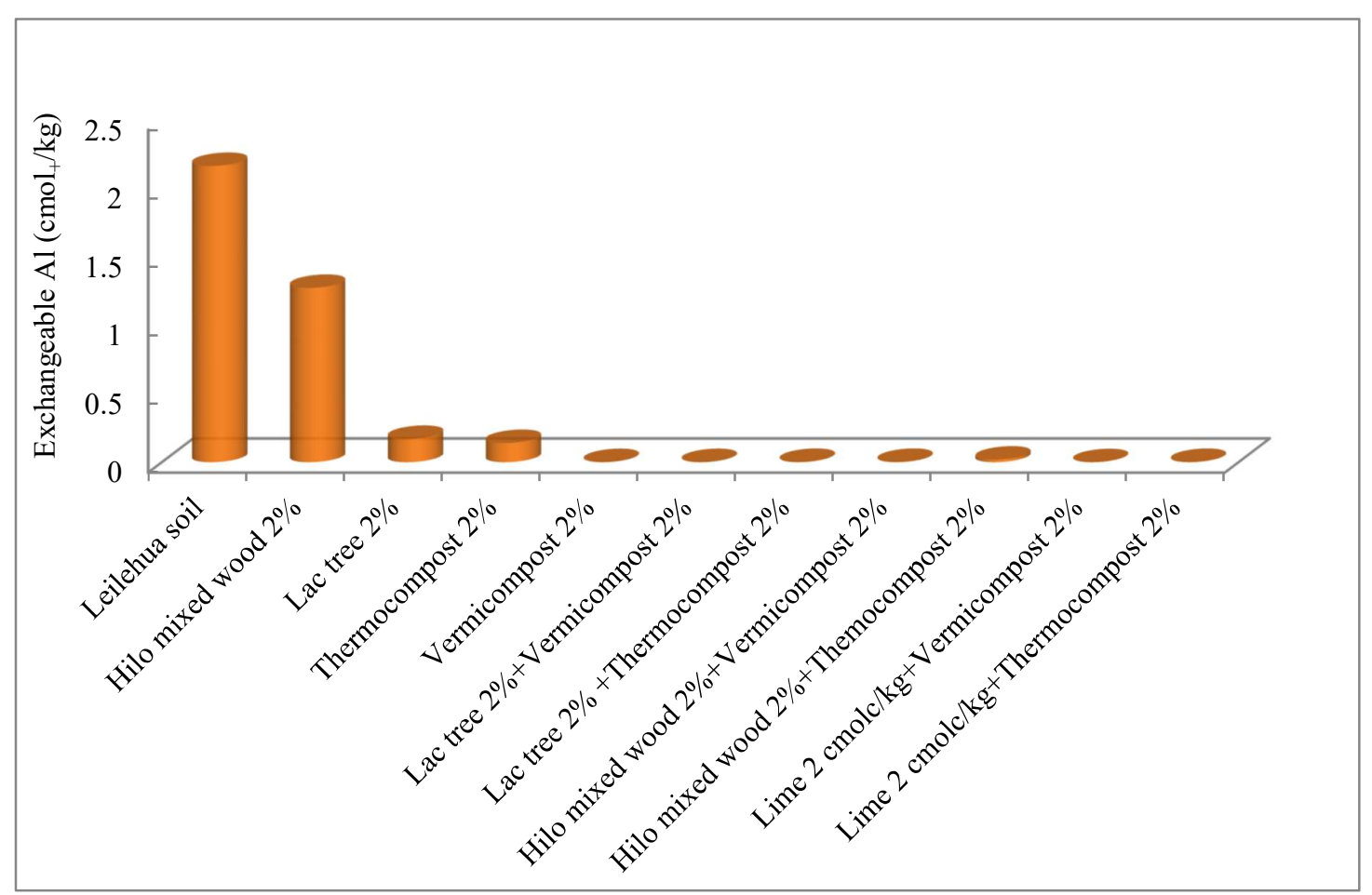

Figure1a. Exchangeable $\mathrm{Al}$ in the Leilehua Ultisol as affected by biochar and compost additions 


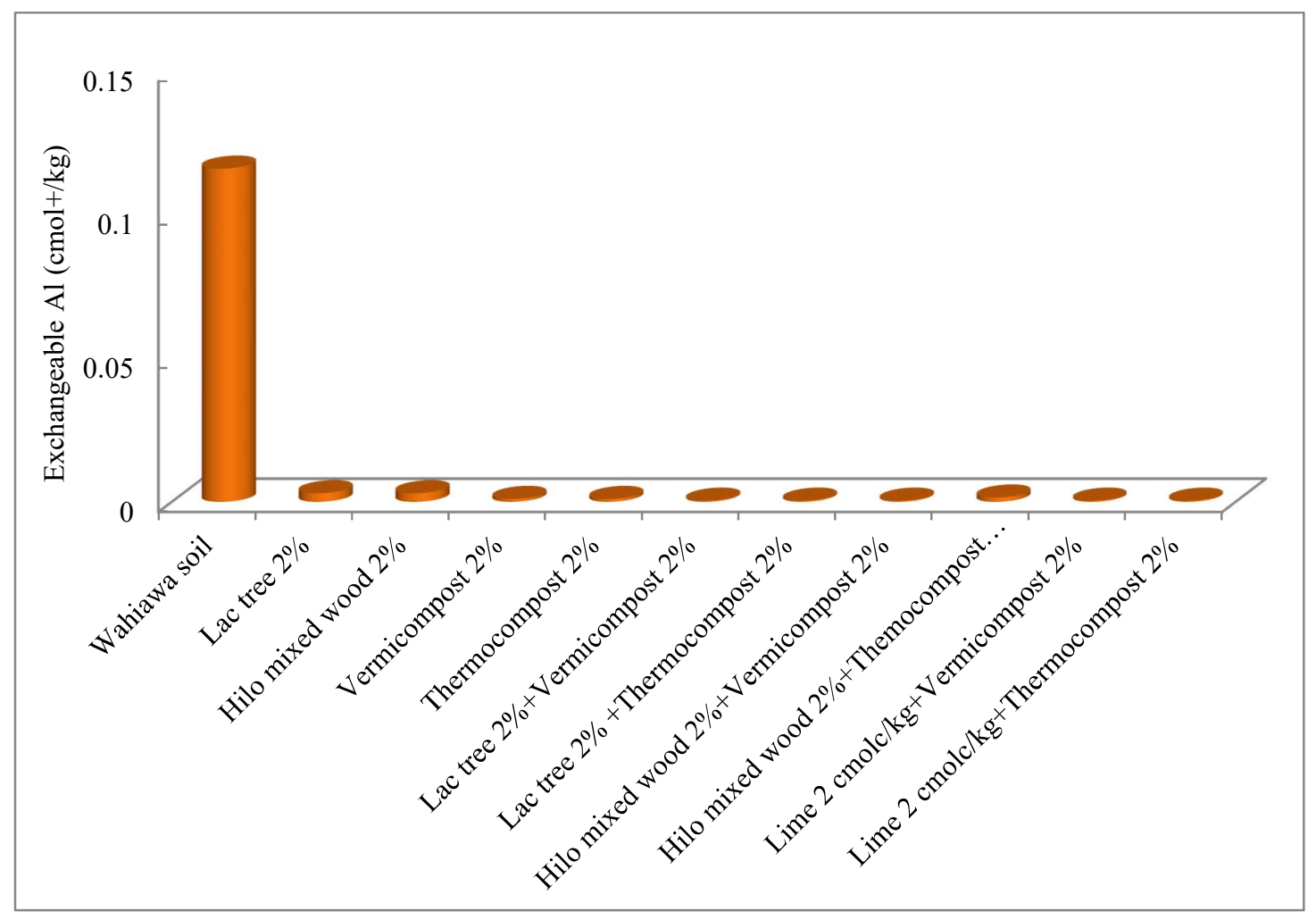

Figure 1b. Exchangeable Al in the Wahiawa Oxisol as affected by biochar and compost additions

\subsection{Nutrient Content in Soils}

Effects of added biochar and compost on soil nutrients were varied, depending on the nutrient, soil, compost and biochar types (Tables 3a-b). Nutrients in the Ultisol (with exception of Fe) were significantly enhanced by compost $(\mathrm{P}<0.01)$ alone, and only $\mathrm{K}, \mathrm{Ca}, \mathrm{Mg}$, and Fe were increased by biochars in combination with composts $(\mathrm{P}<0.01)$, although there was no interaction effect between biochar and compost $(\mathrm{P}>0.05)$ on soil nutrients. Nutrients (with exception of $\mathrm{Mn}$ and $\mathrm{Fe}$ ) in the Oxisol were significantly enriched by the added biochars or composts alone, and only $\mathrm{P}$ and $\mathrm{K}$ were significantly increased $(\mathrm{P}<0.01)$ by the interaction between biochar and compost. Increasing nutrient content by biochar and compost indicated that these amendments contain nutrients or make nutrients more available. For example, Ca was increased by the application of lac tree wood biochar alone at $2 \%$ from $111.8 \mathrm{mg} / \mathrm{kg}$ to $816.9 \mathrm{mg} / \mathrm{kg}$ in the Ultisol and from $715.9 \mathrm{mg} / \mathrm{kg}$ to 1514.4 $\mathrm{mg} / \mathrm{kg}$ in the Oxisol. Such increases in Ca were more than twice of those increases resulted from the Hilo mixed wood biochar. This might be related to the the higher Ca content in the lac tree wood than in the Hilo mixed wood biochar. The combined lac tree wood biochar and vermicompost increased soil $\mathrm{Ca}$ the most. In contrast to $\mathrm{Ca}, \mathrm{K}$ increased more than twice by the thermocompost in combination with either biochar than by the vermicompost, probably due to the higher $\mathrm{K}$ content of the thermocompost (Table 1). Mn and Fe in the Oxisol soil were sharply decreased by the lac tree wood biochar in combination with vermicompost from $805.8 \mathrm{mg} / \mathrm{kg}$ and $63.9 \mathrm{mg} / \mathrm{kg}$ to $361.2 \mathrm{mg} / \mathrm{kg}$ and $36.9 \mathrm{mg} / \mathrm{kg}$, respectively, perhaps due to the higher liming potential of lac tree wood biochar that raised $\mathrm{pH}$ of the Ultisol, and precipitated $\mathrm{Mn}$ and Fe. 
Table 3a. Means and standard errors of $\mathrm{P}, \mathrm{K}$ and $\mathrm{Ca}$ in the soils as affected by biochars and composts additions $(\mathrm{n}=3)$

\begin{tabular}{|c|c|c|c|c|c|c|}
\hline Treatments & P 2 weeks & P 7 weeks & K 2 weeks & $\begin{array}{l}\mathrm{K} 7 \text { weeks } \\
\mathrm{mg} / \mathrm{kg}\end{array}$ & Ca 2 weeks & Ca 7 weeks \\
\hline \multicolumn{7}{|l|}{ Ultisol } \\
\hline Lac tree wood biochar $2 \%$ & $0.8 \pm 0.1 \mathrm{~b}$ & $1.0 \pm 0.1 \mathrm{~b}$ & $25.5 \pm 0.8 \mathrm{c}$ & $70.2 \pm 2.1 \mathrm{~d}$ & $816.9 \pm 40.7 \mathrm{bc}$ & $1112.7 \pm 8.6 \mathrm{~cd}$ \\
\hline Hilo mixed wood biochar $2 \%$ & $1.1 \pm 0.2 \mathrm{~b}$ & $0.9 \pm 0.3 \mathrm{~b}$ & $8.7 \pm 8.3 \mathrm{~cd}$ & $48.2 \pm 2.9 \mathrm{e}$ & $315.5 \pm 8.5 \mathrm{c}$ & $411.3 \pm 89.9 \mathrm{e}$ \\
\hline Vermicompost $2 \%$ & $75.6 \pm 3.5 \mathrm{a}$ & $133.4 \pm 5.4 \mathrm{a}$ & $0.0 \mathrm{~d}$ & $0.0 \mathrm{e}$ & $4038.5 \pm 28.6 \mathrm{a}$ & $4408.9 \pm 339.4 \mathrm{a}$ \\
\hline Thermocompost $2 \%$ & $3.4 \pm 0.7 \mathrm{~b}$ & $4.10 \pm 0.2 b$ & $82.1 \pm 4.3 b$ & $204.2 \pm 4.5 \mathrm{c}$ & $1044.9 \pm 39.3 \mathrm{bc}$ & $1076.5 \pm 67.4 \mathrm{c}$ \\
\hline Lac tree wood $2 \%+$ vermicompost $2 \%$ & $68.0 \pm 13.9 \mathrm{a}$ & $146.2 \pm 14.1 \mathrm{a}$ & $0 \mathrm{~d}$ & $63.2 \pm 7.9 \mathrm{~d}$ & $4166.5 \pm 600.6 \mathrm{a}$ & $5021.0 \pm 227.6 \mathrm{a}$ \\
\hline Lac tree wood $2 \%+$ thermocompost $2 \%$ & $3.1 \pm 0.2 \mathrm{~b}$ & $5.8 \pm 0.1 \mathrm{~b}$ & $140.7 \pm 16.9$ a & $312.6 \pm 8.9 \mathrm{a}$ & $1679.9 \pm 107.1 \mathrm{~b}$ & $2009.9 \pm 51.94 \mathrm{~b}$ \\
\hline Hilo mixed wood $2 \%+$ vermicompost $2 \%$ & $61.8 \pm 3.5 \mathrm{a}$ & $125.4 \pm 4.5 \mathrm{a}$ & $0 \mathrm{~d}$ & $50.0 \pm 1.5 \mathrm{~d}$ & $3548.6 \pm 350.8 \mathrm{a}$ & $4615.8 \pm 127.7$ a \\
\hline Hilo mixed wood $2 \%+$ thermocompost $2 \%$ & $3.7 \pm 0.4 \mathrm{~b}$ & $6.5 \pm 0.6 \mathrm{~b}$ & $114.8 \pm 17.3 \mathrm{ab}$ & $274.6 \pm 5.6 \mathrm{~b}$ & $1230.1 \pm 34.6 \mathrm{bc}$ & $1337.4 \pm 38.5 \mathrm{bc}$ \\
\hline Lime $2 \mathrm{cmol}+/ \mathrm{kg}+$ vermicompost $2 \%$ & $72.9 \pm 0.8$ a & $128.5 \pm 1.6 \mathrm{a}$ & $0.0 \mathrm{~d}$ & $0.0 \mathrm{e}$ & $4171.2 \pm 32.8 \mathrm{a}$ & $5004.5 \pm 164.1 \mathrm{a}$ \\
\hline Lime $2 \mathrm{cmol}+/ \mathrm{kg}$ + thermocompost $2 \%$ & $2.3 \pm 0.2 \mathrm{~b}$ & $5.5 \pm 0.1 \mathrm{~b}$ & $93.7 \pm 0.1 \mathrm{ab}$ & $209.4 \pm 1.4 \mathrm{c}$ & $1529.1 \pm 56.4 \mathrm{bc}$ & $1899.6 \pm 1.6 \mathrm{bc}$ \\
\hline \multicolumn{7}{|l|}{ Oxisol } \\
\hline Lac tree wood biochar $2 \%$ & $37.7 \pm 1.6 \mathrm{~b}$ & $40.2 \pm 1.2 \mathrm{~d}$ & $106.3 \pm 14.0 \mathrm{~d}$ & $136.5 \pm 2.4 \mathrm{ef}$ & $1514.4 \pm 8.7 \mathrm{~cd}$ & $1695.1 \pm 0.6 \mathrm{~d}$ \\
\hline Hilo mixed wood biochar $2 \%$ & $35.8 \pm 0.7 \mathrm{~b}$ & $36.7 \pm 0.0 \mathrm{~d}$ & $64.3 \pm 2.9 \mathrm{~d}$ & $119.9 \pm 0.6 \mathrm{f}$ & $864.2 \pm 5.8 \mathrm{~d}$ & $939.3 \pm 58.8 \mathrm{e}$ \\
\hline Vermicompost $2 \%$ & $285.1 \pm 16.8 \mathrm{a}$ & $365.4 \pm 3.9 \mathrm{a}$ & $65.6 \pm 11.9 \mathrm{~d}$ & $117.4 \pm 4.2 \mathrm{f}$ & $4367.9 \pm 260.3 \mathrm{a}$ & $4609.8 \pm 28.9 \mathrm{~b}$ \\
\hline Thermocompost $2 \%$ & $56.8 \pm 1.7 \mathrm{~b}$ & $60.7 \pm 1.3 \mathrm{c}$ & $241.5 \pm 4.5 \mathrm{bc}$ & $356.2 \pm 1.8 \mathrm{~b}$ & $1556.4 \pm 6.3 \mathrm{~cd}$ & $1962.2 \pm 178.5 \mathrm{~d}$ \\
\hline Lac tree wood $2 \%+$ vermicompost $2 \%$ & $327.4 \pm 31.2 \mathrm{a}$ & $341.6 \pm 2.3 \mathrm{~b}$ & $73.9 \pm 4.0 \mathrm{~d}$ & $162.5 \pm 0.2 \mathrm{de}$ & $4869.6 \pm 45.8 \mathrm{a}$ & $5504.8 \pm 131.8 \mathrm{a}$ \\
\hline Lac tree wood $2 \%+$ thermocompost $2 \%$ & $60.5 \pm 3.7 \mathrm{~b}$ & $68.8 \pm 1.1 \mathrm{c}$ & $313.9 \pm 16.2 \mathrm{a}$ & $406.7 \pm 11.4 \mathrm{a}$ & $2528.5 \pm 263.9 \mathrm{~b}$ & $2770.6 \pm 57.9 \mathrm{c}$ \\
\hline Hilo mixed wood $2 \%+$ vermicompost $2 \%$ & $270.9 \pm 11.1 \mathrm{a}$ & $367.9 \pm 7.2 \mathrm{a}$ & $93.6 \pm 11.4 \mathrm{~d}$ & $174.7 \pm 1.4 \mathrm{~d}$ & $4178.1 \pm 218.8 \mathrm{a}$ & $4682.6 \pm 155.9 \mathrm{~b}$ \\
\hline Hilo mixed wood $2 \%+$ thermocompost $2 \%$ & $64.6 \pm 2.0 \mathrm{~b}$ & $70.2 \pm 1.1 \mathrm{c}$ & $271.6 \pm 20.9 \mathrm{ab}$ & $419.3 \pm 0.3 \mathrm{a}$ & $1708.2 \pm 41.0 \mathrm{c}$ & $1896.0 \pm 103.4 \mathrm{~d}$ \\
\hline Lime $2 \mathrm{cmol}+/ \mathrm{kg}+$ vermicompost $2 \%$ & $295.6 \pm 13.1 \mathrm{a}$ & $353.0 \pm 4.2 \mathrm{ab}$ & $52.9 \pm 8.5 \mathrm{~d}$ & $76.1 \pm 3.4 \mathrm{~g}$ & $4738.2 \pm 47.3 \mathrm{a}$ & $5512.5 \pm 157.1 \mathrm{a}$ \\
\hline Lime $2 \mathrm{cmol}+/ \mathrm{kg}+$ thermocompost $2 \%$ & $57.5 \pm 7.2 \mathrm{~b}$ & $62.7 \pm 0.1 \mathrm{c}$ & $186.5 \pm 4.62 \mathrm{c}$ & $304.7 \pm 8.5 \mathrm{c}$ & $2138.3 \pm 19.5 \mathrm{cb}$ & $2608.4 \pm 96.4 \mathrm{c}$ \\
\hline
\end{tabular}

Table 3b. Means and standard errors of $\mathrm{Mg}, \mathrm{Fe}$ and $\mathrm{Mn}$ in the Leilehua Ultisol as affected by biochars and composts additions $(n=3)$

\begin{tabular}{|c|c|c|c|c|c|c|}
\hline Treatments & Mg 2 weeks & Mg 7 weeks & Fe 2 weeks & $\begin{array}{l}\text { Fe } 7 \text { weeks } \\
\mathrm{mg} / \mathrm{kg}\end{array}$ & Mn 2 weeks & Mn 7 weeks \\
\hline \multicolumn{7}{|l|}{ Ultisol } \\
\hline Lac tree wood biochar $2 \%$ & $136.2 \pm 4.4 \mathrm{~cd}$ & $92.5 \pm 2.6 \mathrm{f}$ & $106.1 \pm 2.1 \mathrm{a}$ & $109.19 \pm 3.01 \mathrm{a}$ & $8.1 \pm 0.2 b$ & $8.1 \pm 0.3 \mathrm{~d}$ \\
\hline Hilo mixed wood biochar $2 \%$ & $134.6 \pm 4.4 \mathrm{~d}$ & $70.9 \pm 3.5 \mathrm{~g}$ & $103.9 \pm 2.5 \mathrm{a}$ & $103.94 \pm 2.73 \mathrm{a}$ & $7.7 \pm 0.5 \mathrm{~b}$ & $8.8 \pm 0.3 \mathrm{~d}$ \\
\hline Vermicompost $2 \%$ & $211.1 \pm 7.1 \mathrm{ab}$ & $185.8 \pm 7.7 \mathrm{~cd}$ & $108.9 \pm 0.7 \mathrm{a}$ & $97.36 \pm 0.98 \mathrm{a}$ & $24.0 \pm 3.9 \mathrm{a}$ & $19.6 \pm 1.6 \mathrm{ab}$ \\
\hline Thermocompost $2 \%$ & $211.9 \pm 9.2 \mathrm{ab}$ & $156.1 \pm 4.9 \mathrm{e}$ & $115.7 \pm 3.9 \mathrm{a}$ & $103.61 \pm 0.29 \mathrm{a}$ & $18.8 \pm 1.1 \mathrm{ab}$ & $14.6 \pm 0.2 \mathrm{c}$ \\
\hline Lac tree wood $2 \%+$ vermicompost $2 \%$ & $183.1 \pm 18.3 b c$ & $209.5 \pm 5.3 b c$ & $113.0 \pm 4.5 \mathrm{a}$ & $115.07 \pm 13.05 \mathrm{a}$ & $23.1 \pm 0.7 \mathrm{a}$ & $20.3 \pm 1.3 \mathrm{a}$ \\
\hline Lac tree wood $2 \%+$ thermocompost $2 \%$ & $209.9 \pm 7.7 \mathrm{ab}$ & $183.9 \pm 3.0 \mathrm{~cd}$ & $109.30 \pm 6.5 \mathrm{a}$ & $118.65 \pm 1.27 \mathrm{a}$ & $24.9 \pm 3.1 \mathrm{a}$ & $14.7 \pm 0.1 \mathrm{c}$ \\
\hline Hilo mixed wood $2 \%+$ vermicompost $2 \%$ & $195.6 \pm 1.4 \mathrm{ab}$ & $192.4 \pm 3.3 \mathrm{~cd}$ & $105.9 \pm 1.2 \mathrm{a}$ & $111.34 \pm 0.54 \mathrm{a}$ & $26.9 \pm 0.9 \mathrm{a}$ & $18.4 \pm 1.5 \mathrm{a}$ \\
\hline Hilo mixed wood $2 \%+$ thermocompost $2 \%$ & $198.4 \pm 7.3 \mathrm{ab}$ & $168.9 \pm 4.8 \mathrm{de}$ & $122.4 \pm 12.0 \mathrm{a}$ & $117.16 \pm 2.13 \mathrm{a}$ & $24.2 \pm 1.1 \mathrm{a}$ & $14.4 \pm 0.0 \mathrm{c}$ \\
\hline Lime $2 \mathrm{cmol}+/ \mathrm{kg}+$ vermicompost $2 \%$ & $240.0 \pm 2.4 \mathrm{a}$ & $248.0 \pm 5.9 \mathrm{a}$ & $99.0 \pm 0.4 \mathrm{a}$ & $99.02 \pm 2.73 \mathrm{a}$ & $23.0 \pm 1.6 \mathrm{a}$ & $18.4 \pm 0.0 \mathrm{bc}$ \\
\hline Lime $2 \mathrm{cmol}+/ \mathrm{kg}+$ thermocompost $2 \%$ & $230.6 \pm 11.6 \mathrm{ab}$ & $232.0 \pm 2.2 \mathrm{ab}$ & $101.0 \pm 0.8 \mathrm{a}$ & $103.55 \pm 8.97 \mathrm{a}$ & $16.9 \pm 3.0 \mathrm{ab}$ & $14.4 \pm 0.3 \mathrm{c}$ \\
\hline \multicolumn{7}{|l|}{ Oxisol } \\
\hline Lac tree wood biochar $2 \%$ & $284.6 \pm 7.1 \mathrm{~cd}$ & $250.8 \pm 4.1 \mathrm{c}$ & $47.3 \pm 10.0 \mathrm{a}$ & $40.92 \pm 0.19 \mathrm{~b}$ & $517.2 \pm 92.2 \mathrm{a}$ & $428.7 \pm 24.9 \mathrm{bcd}$ \\
\hline Hilo mixed wood biochar $2 \%$ & $266.2 \pm 3.6 \mathrm{~d}$ & $232.1 \pm 3.5 c$ & $47.0 \pm 0.1 \mathrm{a}$ & $46.36 \pm 1.77 b$ & $526.3 \pm 14.4 \mathrm{a}$ & $506.1 \pm 30.4 \mathrm{abc}$ \\
\hline Vermicompost 2\% & $351.6 \pm 4.9 \mathrm{abc}$ & $358.3 \pm 9.1 \mathrm{~b}$ & $43.4 \pm 1.3 \mathrm{a}$ & $39.16 \pm 0.46 b$ & $422.7 \pm 1.2 \mathrm{a}$ & $366.3 \pm 4.3 \mathrm{~cd}$ \\
\hline Thermocompost $2 \%$ & $343.9 \pm 7.9 \mathrm{bc}$ & $357.5 \pm 8.8 b$ & $54.6 \pm 2.9 \mathrm{a}$ & $45.93 \pm 1.03 \mathrm{~b}$ & $526.3 \pm 14.3 a$ & $449.0 \pm 0.4 \mathrm{bcd}$ \\
\hline Lac tree wood $2 \%+$ vermicompost $2 \%$ & $369.1 \pm 6.8 \mathrm{ab}$ & $365.3 \pm 0.4 b$ & $44.8 \pm 2.3 \mathrm{a}$ & $40.47 \pm 1.78 \mathrm{~b}$ & $419.3 \pm 4.4 \mathrm{a}$ & $360.9 \pm 7.0 \mathrm{~d}$ \\
\hline Lac tree wood $2 \%+$ thermocompost $2 \%$ & $401.1 \pm 40.8 \mathrm{ab}$ & $353.8 \pm 5.4 b$ & $60.8 \pm 3.6 \mathrm{a}$ & $47.26 \pm 0.42 \mathrm{~b}$ & $634.0 \pm 68.1 \mathrm{a}$ & $481.6 \pm 8.3 \mathrm{bcd}$ \\
\hline Hilo mixed wood $2 \%+$ vermicompost $2 \%$ & $335.2 \pm 3.2 \mathrm{bcd}$ & $361.5 \pm 5.5 b$ & $49.0 \pm 0.1 \mathrm{a}$ & $41.60 \pm 0.64 \mathrm{~b}$ & $464.0 \pm 13.8 \mathrm{a}$ & $425.9 \pm 10.5 \mathrm{bcd}$ \\
\hline Hilo mixed wood $2 \%+$ thermocompost $2 \%$ & $350.0 \pm 1.2 \mathrm{abc}$ & $342.0 \pm 5.9 \mathrm{~b}$ & $58.5 \pm 2.1 \mathrm{a}$ & $54.97 \pm 0.20 \mathrm{~b}$ & $593.4 \pm 10.1 \mathrm{a}$ & $557.1 \pm 2.4 \mathrm{ab}$ \\
\hline Lime $2 \mathrm{cmol}+/ \mathrm{kg}+$ vermicompost $2 \%$ & $422.0 \pm 2.0 \mathrm{a}$ & $406.8 \pm 0.1 \mathrm{a}$ & $47.1 \pm 1.4 \mathrm{a}$ & $48.11 \pm 5.59 \mathrm{~b}$ & $467.4 \pm 9.5 a$ & $415.2 \pm 44.1 \mathrm{bcd}$ \\
\hline Lime $2 \mathrm{cmol}+/ \mathrm{kg}+$ thermocompost $2 \%$ & $391.4 \pm 3.6 \mathrm{ab}$ & $402.8 \pm 1.4 \mathrm{a}$ & $59.9 \pm 3.4 \mathrm{a}$ & $73.18 \pm 7.68 \mathrm{a}$ & $611.4 \pm 47.9 \mathrm{a}$ & $636.6 \pm 54.1 \mathrm{a}$ \\
\hline
\end{tabular}

Means within a column followed by the same letter(s) were not significantly different by Tukey's test at $\alpha=5 \%$. 
2 and 7: weeks after the soils treated with biochars and composts

\subsection{Plant Growth}

Chinese cabbage (Brassica rapa) growth in the Ultisol expressed in shoot dry matter in the second planting was significantly $(\mathrm{P}<0.05)$ affected by the interaction of biochar and compost, while shoot fresh matter, total fresh and dry weights were significantly increased $(\mathrm{P}<0.05)$ by the lac tree wood biochar or compost alone. For example, the shoot fresh weights of cabbage at the first planting in the Ultisol ranged from 4.9 to $29.5 \mathrm{~g}$, and the best growth expressed in shoot or total fresh and dry weights was obtained from the application of lac tree wood biochar in combination with vermicompost (Fig. 2). Shoot, root and total fresh and dry weights of the first planting in the Oxisol were significantly increased by the interaction between biochars and composts; however, there were o significant differences among the treatments.

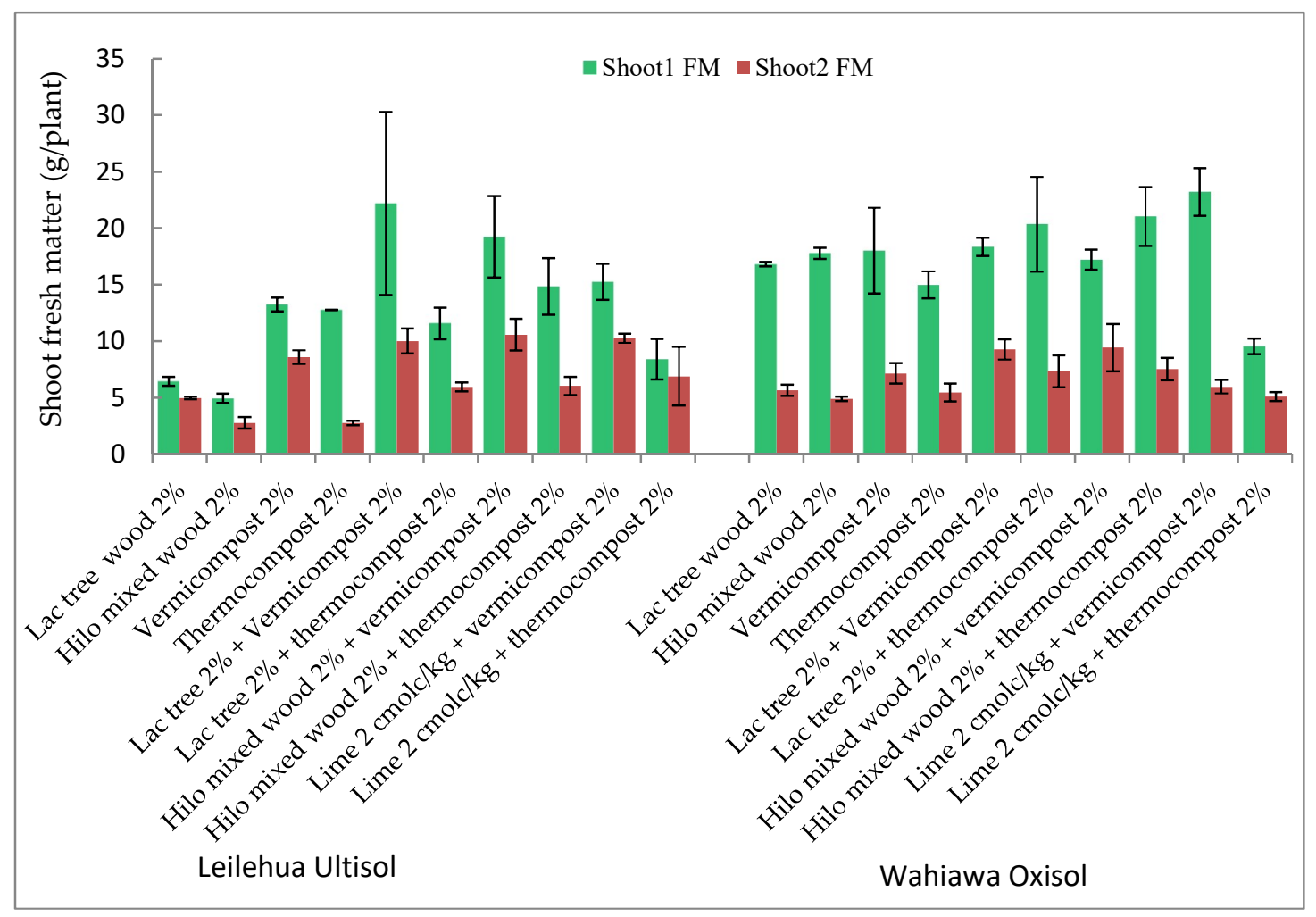

Figure 2. Chinese cabbage shoot fresh weight as affected by biochar and compost additions. $\mathrm{FM}=$ fresh matter, 1 and 2 : first and second plantings; Error bars : Se (n=3)

\subsection{Plant Nutrients}

Phosphorus, K, and Mn concentration in the Chinese cabbage tissues of both plantings in the Ultisol were significantly affected by biochars and composts additions (Table 4a); P and Mn in the Oxisol was significantly affected by biochars (Table $4 \mathrm{~b}$ ); and plant Ca in both soils was significantly increased by the interaction between biochar and compost. Plant $P$ in treatments with compost alone or in combination with biochar was higher than $\mathrm{P}$ in plants treated with biochar alone, probably due to the lower P initial content in the biochars. This might be also the reason why P in plants treated with biochar alone was lower than $0.4 \%$ (a deemed critical level for cabbage growth). It was likely that the added biochar attributed more to their liming effects than $\mathrm{P}$ addition. Nutrient uptake by Chinese cabbage in the Ultisol for $\mathrm{N}, \mathrm{P}, \mathrm{K}$ and $\mathrm{Mg}$ was significantly improved by the lac tree biochar 
in combination with the vermicompost, while nutrient uptake in the Oxisol was not significantly different among the treatments (Table 5, Figs. 3a and 3b).

Table 4a. Means and standard errors of N, P and K in Chinese cabbage tissues as affected by biochar and compost additions $(n=3)$

\begin{tabular}{|c|c|c|c|c|c|c|}
\hline \multirow{3}{*}{ Treatments } & \multicolumn{2}{|c|}{$\mathrm{N}$} & \multicolumn{2}{|l|}{$\mathrm{P}$} & \multicolumn{2}{|l|}{ K } \\
\hline & $1^{\text {st }}$ planting & $2^{\text {nd }}$ planting & $1^{\text {st }}$ planting & $2^{\text {nd }}$ planting & $1^{\text {st }}$ planting & $2^{\text {nd }}$ planting \\
\hline & \multicolumn{6}{|c|}{$\%$} \\
\hline \multicolumn{7}{|l|}{ Leilehua Ultisol } \\
\hline Lac tree wood biochar $2 \%$ & $1.13 \pm 0.03 \mathrm{a}$ & $1.74 \pm 0.25 \mathrm{a}$ & $0.28 \pm 0.05 b$ & $0.22 \pm 0.02 \mathrm{~cd}$ & $3.64 \pm 0.59 \mathrm{ab}$ & $3.46 \pm 0.08 \mathrm{ab}$ \\
\hline Hilo mixed wood biochar $2 \%$ & $1.68 \pm 0.07 \mathrm{a}$ & $1.48 \pm 0.49 \mathrm{a}$ & $0.29 \pm 0.09 \mathrm{~b}$ & $0.05 \pm 0.03 \mathrm{~d}$ & $2.51 \pm 0.89 \mathrm{ab}$ & $1.53 \pm 0.17 \mathrm{~b}$ \\
\hline Vermicompost $2 \%$ & $1.04 \pm 0.10 \mathrm{a}$ & $1.51 \pm 0.02 \mathrm{a}$ & $0.34 \pm 0.03 \mathrm{ab}$ & $0.57 \pm 0.10 \mathrm{ab}$ & $3.04 \pm 0.35 \mathrm{ab}$ & $2.65 \pm 0.03 \mathrm{ab}$ \\
\hline Thermocompost $2 \%$ & $1.86 \pm 0.43 \mathrm{a}$ & $1.66 \pm 0.16 \mathrm{a}$ & $0.65 \pm 0.18 \mathrm{ab}$ & $0.08 \pm 0.01 \mathrm{~cd}$ & $2.67 \pm 0.16 \mathrm{ab}$ & $2.40 \pm 0.24 \mathrm{ab}$ \\
\hline Lac tree wood $2 \%+$ vermicompost $2 \%$ & $1.28 \pm 0.09 \mathrm{a}$ & $1.72 \pm 0.16 \mathrm{a}$ & $0.55 \pm 0.07 \mathrm{ab}$ & $0.47 \pm 0.15 \mathrm{abc}$ & $2.87 \pm 0.58 \mathrm{ab}$ & $3.47 \pm 0.75 \mathrm{ab}$ \\
\hline Lac tree wood $2 \%+$ thermocompost $2 \%$ & $1.12 \pm 0.14 \mathrm{a}$ & $1.63 \pm 0.10 \mathrm{a}$ & $0.57 \pm 0.01 \mathrm{ab}$ & $0.21 \pm 0.03 \mathrm{~cd}$ & $3.57 \pm 0.12 \mathrm{ab}$ & $4.25 \pm 0.77 \mathrm{ab}$ \\
\hline Hilo mixed wood $2 \%+$ vermicompost $2 \%$ & $1.64 \pm 0.46 \mathrm{a}$ & $1.39 \pm 0.04 \mathrm{a}$ & $0.78 \pm 0.01 \mathrm{a}$ & $0.57 \pm 0.01 \mathrm{ab}$ & $2.87 \pm 0.13 \mathrm{ab}$ & $3.11 \pm 0.65 \mathrm{ab}$ \\
\hline Hilo mixed wood $2 \%+$ thermocompost $2 \%$ & $1.09 \pm 0.25 \mathrm{a}$ & $1.77 \pm 0.29 \mathrm{a}$ & $0.51 \pm 0.09 \mathrm{ab}$ & $0.19 \pm 0.04 \mathrm{~cd}$ & $3.83 \pm 0.33 \mathrm{ab}$ & $3.46 \pm 0.35 \mathrm{ab}$ \\
\hline Lime $2 \mathrm{cmol}+/ \mathrm{kg}$ + vermicompost $2 \%$ & $1.30 \pm 0.22 \mathrm{a}$ & $1.95 \pm 0.57 \mathrm{a}$ & $0.63 \pm 0.16 \mathrm{ab}$ & $0.69 \pm 0.04 \mathrm{a}$ & $2.11 \pm 0.32 b$ & $3.24 \pm 0.13 \mathrm{ab}$ \\
\hline Lime $2 \mathrm{cmol}+/ \mathrm{kg}+$ thermocompost $2 \%$ & $1.15 \pm 0.03 \mathrm{a}$ & $1.32 \pm 0.15 \mathrm{a}$ & $0.53 \pm 0.02 \mathrm{ab}$ & $0.29 \pm 0.12 \mathrm{bcd}$ & $5.04 \pm 1.01 \mathrm{a}$ & $4.72 \pm 0.57 \mathrm{a}$ \\
\hline \multicolumn{7}{|l|}{ Wahiawa Oxisol } \\
\hline Lac tree wood biochar $2 \%$ & $1.56 \pm 0.29 \mathrm{a}$ & $1.13 \pm 0.01 \mathrm{a}$ & $0.64 \pm 0.14 \mathrm{a}$ & $0.59 \pm 0.00 \mathrm{a}$ & $4.84 \pm 0.69$ a & $3.68 \pm 0.29 \mathrm{a}$ \\
\hline Hilo mixed wood biochar $2 \%$ & $1.26 \pm 0.15 \mathrm{a}$ & $1.28 \pm 0.32 \mathrm{a}$ & $0.41 \pm 0.12 \mathrm{a}$ & $0.57 \pm 0.09 \mathrm{a}$ & $4.57 \pm 0.63 \mathrm{a}$ & $4.06 \pm 0.14 \mathrm{a}$ \\
\hline Vermicompost $2 \%$ & $1.27 \pm 0.08 \mathrm{a}$ & $1.42 \pm 0.15 \mathrm{a}$ & $0.52 \pm 0.05 \mathrm{a}$ & $0.95 \pm 0.07 \mathrm{a}$ & $2.68 \pm 0.20 \mathrm{a}$ & $3.43 \pm 0.19 \mathrm{a}$ \\
\hline Thermocompost $2 \%$ & $1.35 \pm 0.13 \mathrm{a}$ & $1.62 \pm 0.76 \mathrm{a}$ & $0.55 \pm 0.11 \mathrm{a}$ & $0.90 \pm 0.03 \mathrm{a}$ & $3.09 \pm 0.07 \mathrm{a}$ & $4.94 \pm 0.30 \mathrm{a}$ \\
\hline Lac tree wood $2 \%+$ vermicompost $2 \%$ & $1.31 \pm 0.11 \mathrm{a}$ & $1.35 \pm 0.16 \mathrm{a}$ & $0.79 \pm 0.01 \mathrm{a}$ & $0.74 \pm 0.22 \mathrm{a}$ & $3.38 \pm 1.11 \mathrm{a}$ & $3.95 \pm 0.51 \mathrm{a}$ \\
\hline Lac tree wood $2 \%+$ thermocompost $2 \%$ & $1.32 \pm 0.14 \mathrm{a}$ & $1.61 \pm 0.49 \mathrm{a}$ & $0.69 \pm 0.03 \mathrm{a}$ & $0.56 \pm 0.19 \mathrm{a}$ & $2.96 \pm 0.07$ a & $4.02 \pm 1.45 \mathrm{a}$ \\
\hline Hilo mixed wood $2 \%+$ vermicompost $2 \%$ & $1.81 \pm 0.19 \mathrm{a}$ & $1.85 \pm 0.45 \mathrm{a}$ & $0.63 \pm 0.09 \mathrm{a}$ & $0.73 \pm 0.07 \mathrm{a}$ & $4.24 \pm 0.72 \mathrm{a}$ & $4.91 \pm 0.81 \mathrm{a}$ \\
\hline Hilo mixed wood $2 \%+$ thermocompost $2 \%$ & $1.17 \pm 0.05 \mathrm{a}$ & $1.73 \pm 0.14 \mathrm{a}$ & $0.68 \pm 0.08 \mathrm{a}$ & $0.81 \pm 0.05$ a & $3.41 \pm 0.02 \mathrm{a}$ & $4.61 \pm 0.49 \mathrm{a}$ \\
\hline Lime $2 \mathrm{cmol}+/ \mathrm{kg}$ + vermicompost $2 \%$ & $1.41 \pm 0.32 \mathrm{a}$ & $1.46 \pm 0.16 \mathrm{a}$ & $0.86 \pm 0.00 \mathrm{a}$ & $0.50 \pm 0.03 \mathrm{a}$ & $3.76 \pm 1.28$ a & $2.54 \pm 0.38 \mathrm{a}$ \\
\hline Lime $2 \mathrm{cmol}+/ \mathrm{kg}$ + thermocompost $2 \%$ & $1.63 \pm 0.15 \mathrm{a}$ & $1.53 \pm 0.01 \mathrm{a}$ & $0.75 \pm 0.18 \mathrm{a}$ & $0.53 \pm 0.09 \mathrm{a}$ & $3.49 \pm 0.07 \mathrm{a}$ & $3.02 \pm 0.41 \mathrm{a}$ \\
\hline Sufficiency level for Brassica rapa (\%) & \multicolumn{2}{|c|}{$3-4$} & \multicolumn{2}{|l|}{$0.4-0.7$} & \multicolumn{2}{|c|}{$4.5-7.5$} \\
\hline
\end{tabular}

Table 4b. Means and standard errors of $\mathrm{Ca}, \mathrm{Mg}, \mathrm{Fe}$ and $\mathrm{Mn}$ in Chinese cabbage tissues as affected by biochar and compost additions $(\mathrm{n}=3)$

\begin{tabular}{|c|c|c|c|c|c|c|c|c|}
\hline \multirow{2}{*}{ Treatments } & \multirow{2}{*}{$\begin{array}{c}\mathrm{Ca} \\
1^{\text {st }} \text { planting } \\
\% \\
\end{array}$} & \multirow[b]{2}{*}{$2^{\text {nd }}$ planting } & \multirow{2}{*}{$\begin{array}{c}\mathrm{Mg} \\
1^{\text {st }} \text { planting } \\
\% \\
\end{array}$} & \multirow[b]{2}{*}{$2^{\text {nd }}$ planting } & \multirow{2}{*}{$\begin{array}{c}\text { Fe } \\
1^{\text {st }} \text { planting } \\
\mathrm{mg} / \mathrm{kg}\end{array}$} & \multirow[b]{2}{*}{$2^{\text {nd }}$ planting } & \multicolumn{2}{|l|}{ Mn } \\
\hline & & & & & & & $\begin{array}{c}1^{\text {st }} \text { planting } \\
\mathrm{mg} / \mathrm{kg}\end{array}$ & $2^{\text {nd }}$ planting \\
\hline Lac tree wood biochar $2 \%$ & $3.38 \pm 0.08 \mathrm{a}$ & $3.91 \pm 1.06$ a & $0.56 \pm 0.06 \mathrm{a}$ & $0.98 \pm 0.25 \mathrm{a}$ & $120.0 \pm 58.3 \mathrm{a}$ & $81.6 \pm 18.3 \mathrm{a}$ & $42.8 \pm 21.5 \mathrm{a}$ & $64.7 \pm 23.9 \mathrm{a}$ \\
\hline Hilo mixed wood biochar $2 \%$ & $2.28 \pm 0.41 \mathrm{a}$ & $2.08 \pm 0.04 \mathrm{a}$ & $0.64 \pm 0.09 \mathrm{a}$ & $0.96 \pm 0.24 \mathrm{a}$ & $192.8 \pm 41.4 \mathrm{a}$ & $77.7 \pm 25.4 \mathrm{a}$ & $79.0 \pm 33.9 \mathrm{a}$ & $71.9 \pm 30.7 \mathrm{a}$ \\
\hline Vermicompost $2 \%$ & $2.57 \pm 0.57 \mathrm{a}$ & $3.29 \pm 0.05 \mathrm{a}$ & $0.59 \pm 0.09 \mathrm{a}$ & $0.85 \pm 0.15 \mathrm{a}$ & $104.1 \pm 8.0 \mathrm{a}$ & $71.2 \pm 18.7 \mathrm{a}$ & $31.1 \pm 0.4 \mathrm{a}$ & $75.5 \pm 14.9 \mathrm{a}$ \\
\hline Thermocompost $2 \%$ & $3.59 \pm 1.09 \mathrm{a}$ & $2.21 \pm 0.30 \mathrm{a}$ & $0.49 \pm 0.08 \mathrm{a}$ & $0.53 \pm 0.04 \mathrm{a}$ & $118.0 \pm 6.9 \mathrm{a}$ & $59.3 \pm 29.3 \mathrm{a}$ & $25.8 \pm 7.8$ a & $42.8 \pm 10.5 \mathrm{a}$ \\
\hline Lac tree wood $2 \%+$ vermicompost $2 \%$ & $3.87 \pm 0.21 \mathrm{a}$ & $4.09 \pm 0.59 \mathrm{a}$ & $0.43 \pm 0.03 \mathrm{a}$ & $0.65 \pm 0.19 \mathrm{a}$ & $69.6 \pm 7.6 \mathrm{a}$ & $50.9 \pm 6.1 \mathrm{a}$ & $14.2 \pm 3.8 \mathrm{a}$ & $61.7 \pm 9.3 \mathrm{a}$ \\
\hline Lac tree wood $2 \%+$ thermocompost $2 \%$ & $2.70 \pm 0.14$ a & $3.58 \pm 0.35 \mathrm{a}$ & $0.56 \pm 0.07 \mathrm{a}$ & $0.70 \pm 0.07 \mathrm{a}$ & $119.5 \pm 44.1 \mathrm{a}$ & $82.9 \pm 7.8 \mathrm{a}$ & $41.7 \pm 4.4 \mathrm{a}$ & $73.1 \pm 7.9 \mathrm{a}$ \\
\hline Hilo mixed wood $2 \%+$ vermicompost $2 \%$ & $3.51 \pm 0.43 \mathrm{a}$ & $4.16 \pm 0.21 \mathrm{a}$ & $0.42 \pm 0.02 \mathrm{a}$ & $0.70 \pm 0.09 \mathrm{a}$ & $88.5 \pm 22.6$ a & $64.1 \pm 11.8$ a & $16.3 \pm 2.0 \mathrm{a}$ & $50.9 \pm 11.9$ a \\
\hline Hilo mixed wood $2 \%+$ thermocompost $2 \%$ & $2.43 \pm 0.33 \mathrm{a}$ & $2.57 \pm 0.02 \mathrm{a}$ & $0.51 \pm 0.00 \mathrm{a}$ & $0.57 \pm 0.12 \mathrm{a}$ & $92.6 \pm 1.9 \mathrm{a}$ & $144.9 \pm 60.5 \mathrm{a}$ & $36.0 \pm 10.6 \mathrm{a}$ & $61.4 \pm 12.8$ a \\
\hline Lime $2 \mathrm{cmol}_{+} / \mathrm{kg}+$ vermicompost $2 \%$ & $3.50 \pm 0.19 \mathrm{a}$ & $2.51 \pm 0.85 \mathrm{a}$ & $0.52 \pm 0.12 \mathrm{a}$ & $0.75 \pm 0.07 \mathrm{a}$ & $126.4 \pm 9.1 \mathrm{a}$ & $69.6 \pm 22.3 \mathrm{a}$ & $26.4 \pm 1.4 \mathrm{a}$ & $82.8 \pm 0.7 \mathrm{a}$ \\
\hline
\end{tabular}




\begin{tabular}{|c|c|c|c|c|c|c|c|c|}
\hline Lime $2 \mathrm{cmol}+/ \mathrm{kg}$ + thermocompost $2 \%$ & $3.84 \pm 0.05 \mathrm{a}$ & $4.38 \pm 0.51 \mathrm{a}$ & $0.74 \pm 0.06 \mathrm{a}$ & $0.92 \pm 0.16 \mathrm{a}$ & $145.9 \pm 21.4 \mathrm{a}$ & $92.0 \pm 10.2 \mathrm{a}$ & $74.3 \pm 8.9 \mathrm{a}$ & $78.6 \pm 40.3 \mathrm{a}$ \\
\hline \multicolumn{9}{|l|}{ Wahiawa Oxisol } \\
\hline Lac tree wood biochar $2 \%$ & $3.06 \pm 0.32 \mathrm{ab}$ & $3.57 \pm 0.16$ a & $0.51 \pm 0.04 \mathrm{a}$ & $0.83 \pm 0.10 \mathrm{a}$ & $197.4 \pm 87.5 \mathrm{a}$ & $108.4 \pm 36.4 \mathrm{a}$ & $113.7 \pm 18.8$ a & $145.9 \pm 34.1 \mathrm{a}$ \\
\hline Hilo mixed wood biochar $2 \%$ & $2.32 \pm 0.41 \mathrm{~b}$ & $3.15 \pm 0.81 \mathrm{a}$ & $0.65 \pm 0.08 \mathrm{a}$ & $1.08 \pm 0.29 \mathrm{a}$ & $81.2 \pm 23.3 \mathrm{a}$ & $108.4 \pm 42.9 \mathrm{a}$ & $103.7 \pm 20.3 \mathrm{a}$ & $120.3 \pm 30.8 \mathrm{a}$ \\
\hline Vermicompost $2 \%$ & $2.07 \pm 0.08 \mathrm{~b}$ & $3.79 \pm 0.03$ a & $0.39 \pm 0.01 \mathrm{a}$ & $0.73 \pm 0.00 \mathrm{a}$ & $106.6 \pm 19.2 \mathrm{a}$ & $57.7 \pm 6.3 \mathrm{a}$ & $73.3 \pm 12.7$ a & $163.5 \pm 15.9 \mathrm{a}$ \\
\hline Thermocompost $2 \%$ & $3.04 \pm 0.65 \mathrm{ab}$ & $3.56 \pm 0.86$ a & $0.64 \pm 0.12 \mathrm{a}$ & $0.94 \pm 0.15 \mathrm{a}$ & $165.1 \pm 8.4 \mathrm{a}$ & $230.9 \pm 61.3 \mathrm{a}$ & $75.8 \pm 3.4 \mathrm{a}$ & $113.9 \pm 30.6 \mathrm{a}$ \\
\hline Lac tree wood $2 \%+$ vermicompost $2 \%$ & $3.01 \pm 0.27 \mathrm{ab}$ & $2.35 \pm 0.92 \mathrm{a}$ & $0.49 \pm 0.04 \mathrm{a}$ & $0.92 \pm 0.09 \mathrm{a}$ & $133.4 \pm 17.8 \mathrm{a}$ & $74.1 \pm 6.6 \mathrm{a}$ & $115.8 \pm 10.5 \mathrm{a}$ & $196.7 \pm 3.0 \mathrm{a}$ \\
\hline Lac tree wood $2 \%+$ thermocompost $2 \%$ & $2.71 \pm 0.21 \mathrm{ab}$ & $3.26 \pm 0.01 \mathrm{a}$ & $0.44 \pm 0.03 \mathrm{a}$ & $0.81 \pm 0.02 \mathrm{a}$ & $67.4 \pm 4.9 \mathrm{a}$ & $80.3 \pm 17.8$ a & $122.5 \pm 6.3 \mathrm{a}$ & $160.1 \pm 9.6 \mathrm{a}$ \\
\hline Hilo mixed wood $2 \%+$ vermicompost $2 \%$ & $3.27 \pm 0.53 \mathrm{ab}$ & $3.88 \pm 0.60 \mathrm{a}$ & $0.47 \pm 0.07$ a & $0.69 \pm 0.04 \mathrm{a}$ & $120.1 \pm 80.2 \mathrm{a}$ & $83.4 \pm 4.5$ a & $113.2 \pm 25.9 \mathrm{a}$ & $181.3 \pm 27.1 \mathrm{a}$ \\
\hline Hilo mixed wood $2 \%+$ thermocompost $2 \%$ & $2.18 \pm 0.19 \mathrm{~b}$ & $3.73 \pm 0.42 \mathrm{a}$ & $0.45 \pm 0.05 \mathrm{a}$ & $0.83 \pm 0.03 \mathrm{a}$ & $80.29 \pm 1.5 \mathrm{a}$ & $100.9 \pm 44.0 \mathrm{a}$ & $80.9 \pm 2.2 \mathrm{a}$ & $108.2 \pm 0.3 \mathrm{a}$ \\
\hline Lime $2 \mathrm{cmol}_{+} / \mathrm{kg}$ + vermicompost $2 \%$ & $4.35 \pm 0.15 \mathrm{a}$ & $3.36 \pm 0.26$ a & $0.62 \pm 0.03 \mathrm{a}$ & $0.63 \pm 0.00 \mathrm{a}$ & $140.1 \pm 62.3 \mathrm{a}$ & $70.7 \pm 26.9$ a & $125.9 \pm 29.4 \mathrm{a}$ & $159.7 \pm 25.3 \mathrm{a}$ \\
\hline Lime $2 \mathrm{cmol}+/ \mathrm{kg} \quad+$ thermocompost $2 \%$ & $2.75 \pm 0.04 \mathrm{~b}$ & $3.02 \pm 0.04 \mathrm{a}$ & $0.48 \pm 0.00 \mathrm{a}$ & $0.83 \pm 0.15 \mathrm{a}$ & $119.6 \pm 14.3 \mathrm{a}$ & $64.5 \pm 21.3 \mathrm{a}$ & $125.2 \pm 13.3 \mathrm{a}$ & $116.9 \pm 2.4 \mathrm{a}$ \\
\hline Sufficiency level for Brassica rapa & $1.9-6.0$ & & $0.23-0.75$ & & $40-300$ & & $25-200$ & \\
\hline
\end{tabular}

Means within a column followed by the same letter(s) were not significantly different by Tukey's test at $\alpha=5 \%$.

Table 5.Total nutrient uptake by Brassica rapa in Leilehua Ultisol as affected by biochar and compost additions $(\mathrm{n}=3)$

\begin{tabular}{|c|c|c|c|c|c|c|c|}
\hline Treatments & $\mathrm{N}$ & $\mathrm{P}$ & K & $\begin{array}{l}\mathrm{Ca} \\
\mathrm{mg} / \text { plant }\end{array}$ & $\mathrm{Mg}$ & $\mathrm{Fe}$ & $\mathrm{Mn}$ \\
\hline \multicolumn{8}{|l|}{ Leilehua Ultisol } \\
\hline Lac tree wood biochar $2 \%$ & $20.7 \pm 0.1 \mathrm{bc}$ & $4.0 \pm 1.0 \mathrm{~b}$ & $54.4 \pm 1.4 \mathrm{bcd}$ & $3.91 \pm 1.06 \mathrm{a}$ & $11.1 \pm 0.4 \mathrm{dc}$ & $0.17 \pm 0.06 \mathrm{a}$ & $0.08 \pm 0.01 \mathrm{a}$ \\
\hline Hilo mixed wood biochar $2 \%$ & $11.4 \pm 4.2 \mathrm{c}$ & $11.4 \pm 4.2 \mathrm{~b}$ & $17.6 \pm 9.2 \mathrm{~d}$ & $2.08 \pm 0.04 \mathrm{a}$ & $5.7 \pm 0.6 \mathrm{~d}$ & $0.1 \pm 0.01 \quad \mathrm{a}$ & $0.06 \pm 0.04 \mathrm{a}$ \\
\hline Vermicompost $2 \%$ & $35.9 \pm 0.8 \mathrm{abc}$ & $12.6 \pm 1.1 \mathrm{ab}$ & $85.6 \pm 4.4 \mathrm{abcd}$ & $3.29 \pm 0.05 \mathrm{a}$ & $20.5 \pm 0.0 \mathrm{ab}$ & $0.27 \pm 0.03 \mathrm{a}$ & $0.14 \pm 0.01 \mathrm{a}$ \\
\hline Thermocompost $2 \%$ & $28.4 \pm 10.7 \mathrm{bc}$ & $8.5 \pm 4.1 \mathrm{ab}$ & $39.2 \pm 10.2 \mathrm{~cd}$ & $2.21 \pm 0.30 \mathrm{a}$ & $7.2 \pm 0.6 \mathrm{~d}$ & $0.16 \pm 0.05 \mathrm{a}$ & $0.05 \pm 0.01 \mathrm{a}$ \\
\hline Lac tree wood $2 \%+$ Vermicompost $2 \%$ & $66.5 \pm 11.7 \mathrm{a}$ & $26.6 \pm 8.0 \mathrm{a}$ & $139.7 \pm 7.6 \mathrm{a}$ & $4.09 \pm 0.59 \mathrm{a}$ & $22.9 \pm 2.5 \mathrm{a}$ & $0.31 \pm 0.05 \mathrm{a}$ & $0.12 \pm 0.0 \quad \mathrm{a}$ \\
\hline Lac tree wood $2 \%+$ Thermocompost $2 \%$ & $28.1 \pm 1.5 \mathrm{bc}$ & $9.2 \pm 0.4 \mathrm{ab}$ & $82.4 \pm 12.2 \mathrm{abcd}$ & $3.58 \pm 0.35 \mathrm{a}$ & $13.2 \pm 0.8 \mathrm{bcd}$ & $0.23 \pm 0.07 \mathrm{a}$ & $0.12 \pm 0.01 \mathrm{a}$ \\
\hline Hilo mixed wood $2 \%+$ vermicompost $2 \%$ & $52.9 \pm 0.6 \mathrm{ab}$ & $25.9 \pm 5.7$ a & $110.9 \pm 6.1 \mathrm{abc}$ & $4.16 \pm 0.21 \mathrm{a}$ & $19.8 \pm 0.2 \mathrm{abc}$ & $0.27 \pm 0.01 \mathrm{a}$ & $0.11 \pm 0.01 \mathrm{a}$ \\
\hline Hilo mixed wood $2 \%+$ Thermocompost $2 \%$ & $39.7 \pm 4.5 \mathrm{abc}$ & $13.1 \pm 0.1 \mathrm{ab}$ & $122.2 \pm 18.2 \mathrm{ab}$ & $2.57 \pm 0.02 \mathrm{a}$ & $18.2 \pm 0.8 \mathrm{abc}$ & $0.29 \pm 0.06$ a & $0.14 \pm 0.02 \mathrm{a}$ \\
\hline Lime $2 \mathrm{cmol}+/ \mathrm{kg}+$ vermicompost $2 \%$ & $30.8 \pm 6.5 \mathrm{bc}$ & $14.5 \pm 3.2 \mathrm{ab}$ & $55.7 \pm 18.5 \mathrm{bcd}$ & $2.51 \pm 0.85 \mathrm{a}$ & $12.7 \pm 3.1 \mathrm{bcd}$ & $0.24 \pm 0.05 \mathrm{a}$ & $0.09 \pm 0.04 \mathrm{a}$ \\
\hline Lime $2 \mathrm{cmol}+\mathrm{kg}$ + thermocompost $2 \%$ & $25.6 \pm 2.9 \mathrm{bc}$ & $9.0 \pm 0.2 \mathrm{ab}$ & $104.2 \pm 23.7 \mathrm{abc}$ & $4.38 \pm 0.51 \mathrm{a}$ & $17.1 \pm 2.8 \mathrm{abc}$ & $0.26 \pm 0.04 \mathrm{a}$ & $0.15 \pm 0.06 \mathrm{a}$ \\
\hline \multicolumn{8}{|l|}{ Wahiawa Oxisol } \\
\hline Lac tree wood biochar $2 \%$ & $39.7 \pm 4.3 \mathrm{ab}$ & $17.2 \pm 2.0 \mathrm{a}$ & $124.7 \pm 6.5$ a & $88.7 \pm 4.4 \mathrm{ab}$ & $16.6 \pm 1.1 \mathrm{a}$ & $0.47 \pm 0.13$ a & $0.34 \pm 0.0 \mathrm{abc}$ \\
\hline Hilo mixed wood biochar $2 \%$ & $32.8 \pm 0.4 \mathrm{ab}$ & $11.7 \pm 1.7 \mathrm{a}$ & $117.1 \pm 10.3 \mathrm{a}$ & $64.9 \pm 2.9 \mathrm{ab}$ & $19.4 \pm 0.2 \mathrm{a}$ & $0.22 \pm 0.02 \mathrm{a}$ & $0.28 \pm 0.02 \mathrm{bc}$ \\
\hline Vermicompost $2 \%$ & $41.1 \pm 11 \mathrm{ab}$ & $19.6 \pm 4.2 \mathrm{a}$ & $88.0 \pm 16.4$ a & $80.2 \pm 20.7 \mathrm{ab}$ & $15.1 \pm 3.3 \mathrm{a}$ & $0.27 \pm 0.05 \mathrm{a}$ & $0.29 \pm 0.03 \mathrm{abc}$ \\
\hline Thermocompost $2 \%$ & $32.9 \pm 0.9 \mathrm{ab}$ & $15.0 \pm 1.2 \mathrm{a}$ & $85.3 \pm 8.1 \mathrm{a}$ & $71.6 \pm 1.4 \mathrm{ab}$ & $16.4 \pm 0.0 \mathrm{a}$ & $0.41 \pm 0.15 \mathrm{a}$ & $0.20 \pm 0.03 \mathrm{c}$ \\
\hline Lac tree wood $2 \%+$ Vermicompost $2 \%$ & $43.9 \pm 1.3 \mathrm{ab}$ & $25.9 \pm 0.7 \mathrm{a}$ & $124.5 \pm 33.2 \mathrm{a}$ & $91.9 \pm 16.6 \mathrm{ab}$ & $20.9 \pm 0.1 \mathrm{a}$ & $0.37 \pm 0.01 \mathrm{a}$ & $0.47 \pm 0.02 \mathrm{a}$ \\
\hline Lac tree wood $2 \%+$ Thermocompost $2 \%$ & $41.1 \pm 2.2 \mathrm{ab}$ & $20.9 \pm 0.4 \mathrm{a}$ & $105.9 \pm 9.6$ a & $88.2 \pm 2.3 \mathrm{ab}$ & $16.7 \pm 1.0 \mathrm{a}$ & $0.21 \pm 0.01 \mathrm{a}$ & $0.42 \pm 0.01 \mathrm{ab}$ \\
\hline Hilo mixed wood $2 \%+$ vermicompost $2 \%$ & $58.2 \pm 2.4 \mathrm{a}$ & $21.8 \pm 2.7 \mathrm{a}$ & $148.5 \pm 2.8 \mathrm{a}$ & $113.7 \pm 17.6 \mathrm{ab}$ & $18.2 \pm 1.6 \mathrm{a}$ & $0.34 \pm 0.03 \mathrm{a}$ & $0.45 \pm 0.07 \mathrm{ab}$ \\
\hline Hilo mixed wood $2 \%+$ Thermocompost $2 \%$ & $46.4 \pm 9.8 \mathrm{ab}$ & $25.5 \pm 6.7 \mathrm{a}$ & $134.2 \pm 30.9 \mathrm{a}$ & $93.7 \pm 29.1 \mathrm{ab}$ & $19.7 \pm 6.0 \mathrm{a}$ & $0.29 \pm 0.03 \mathrm{a}$ & $0.32 \pm 0.05 \mathrm{abc}$ \\
\hline Lime $2 \mathrm{cmol}+/ \mathrm{kg}+$ vermicompost $2 \%$ & $48.5 \pm 0.5 \mathrm{ab}$ & $27.7 \pm 5.8 \mathrm{a}$ & $117.5 \pm 6.7$ a & $144.5 \pm 23.2 \mathrm{a}$ & $22.2 \pm 5.3 \mathrm{a}$ & $0.41 \pm 0.10 \mathrm{a}$ & $0.45 \pm 0.01 \mathrm{ab}$ \\
\hline Lime $2 \mathrm{cmol}_{+} / \mathrm{kg}+$ thermocompost $2 \%$ & $26.3 \pm 1.8 \mathrm{~b}$ & $10.9 \pm 0.1 \mathrm{a}$ & $55.6 \pm 9.3 \mathrm{a}$ & $47.7 \pm 6.4 \mathrm{~b}$ & $10.2 \pm 2.1 \mathrm{a}$ & $0.17 \pm 0.05 \mathrm{a}$ & $0.20 \pm 0.01 \mathrm{c}$ \\
\hline
\end{tabular}

Means within a column followed by the same letter(s) were not significantly different by Tukey's test at $\alpha=5 \%$. 
11 of 16

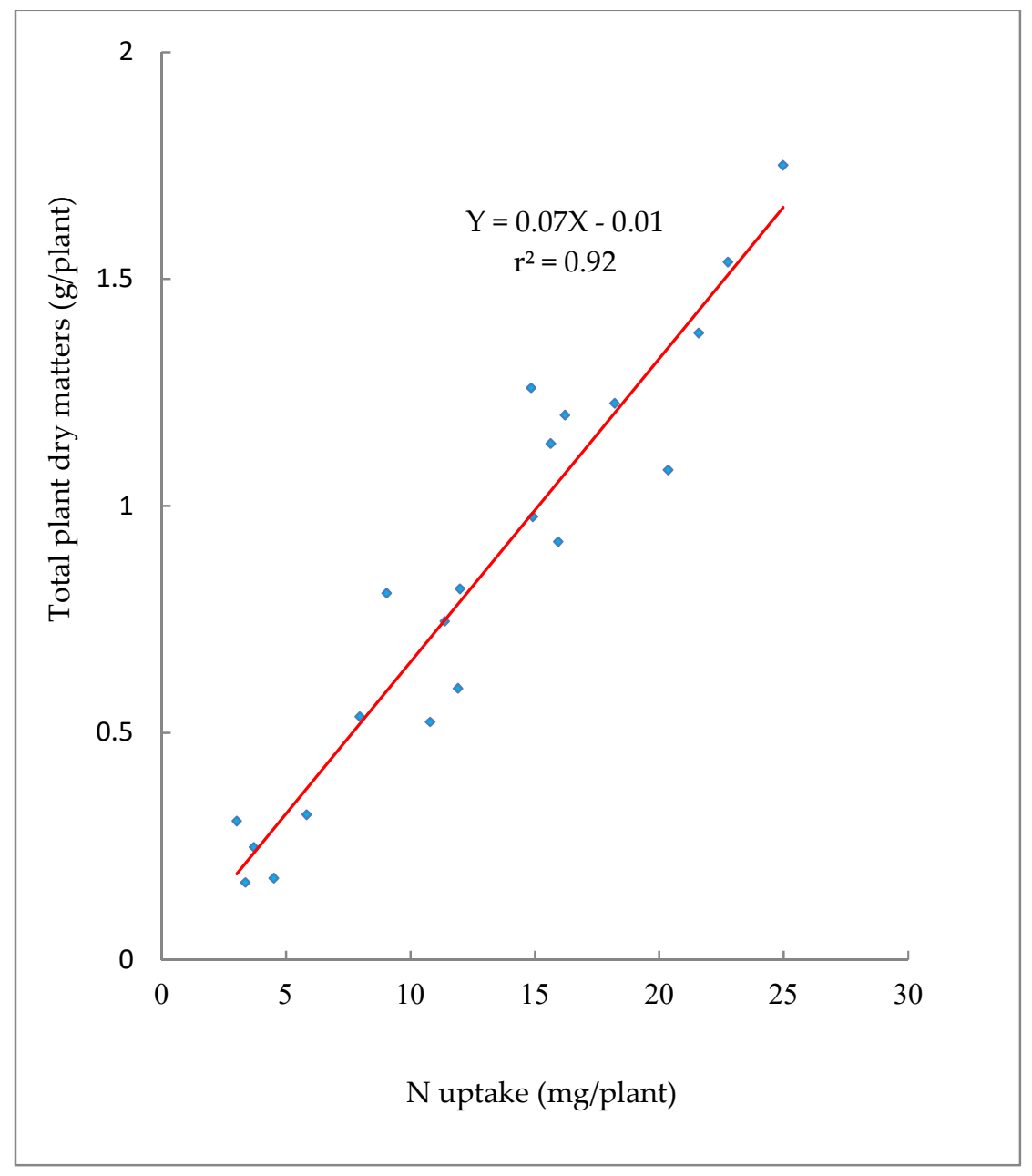

Figure 3a. Relationship between $\mathrm{N}$ uptake and total dry matter of Chinese cabbage of second planting in the Leilehua Ultisol soil 


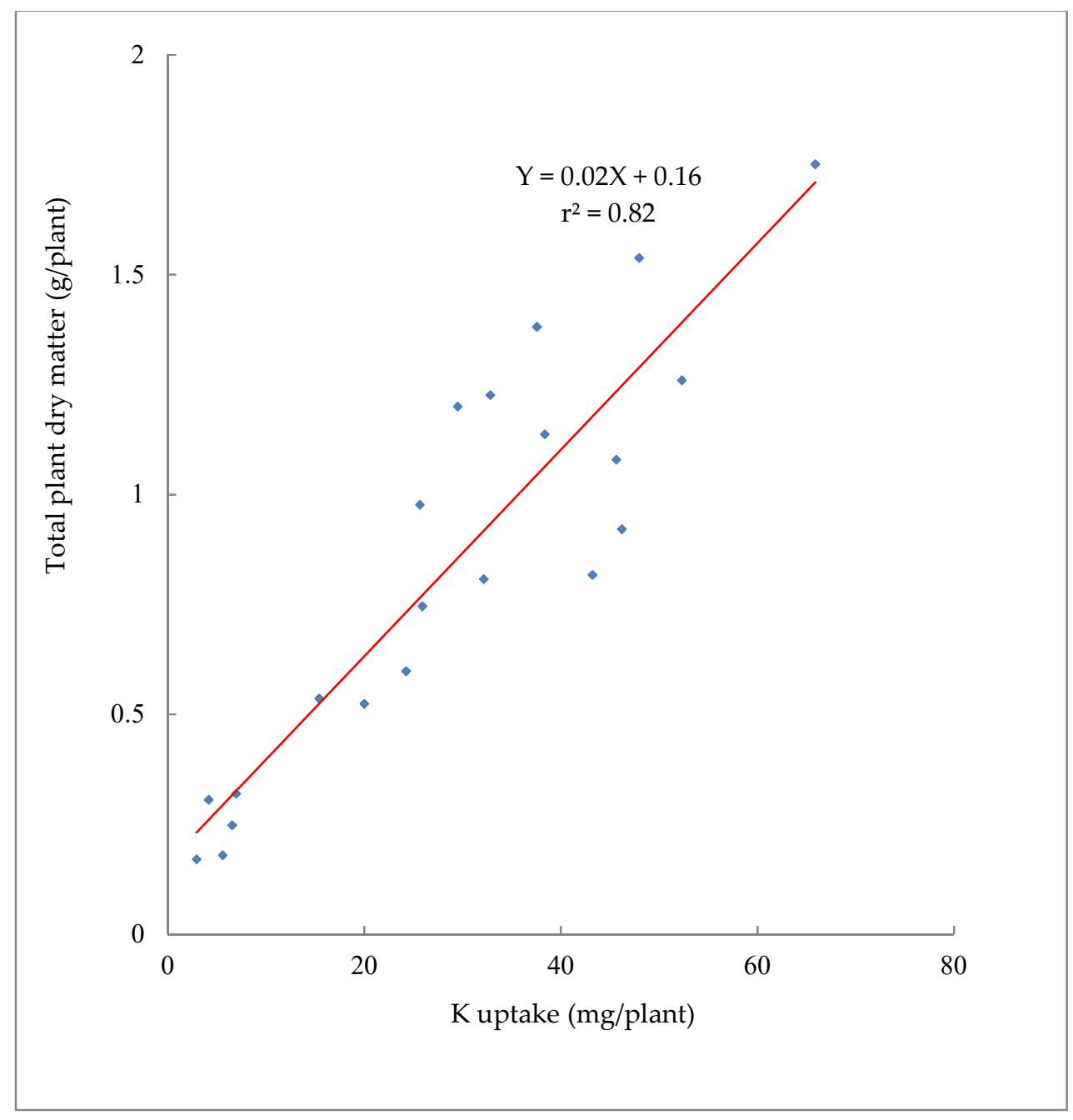

Figure 3b. Relationship between $\mathrm{K}$ uptake and total dry matter of Chinese cabbage of second planting in the Leilehua Ultisol soil.

\section{Discussion}

Additions of biochars in combination with composts increased acid soils $\mathrm{pH}$ and decreased exchangeable aluminum. Such effects could be attributed to the alkalinity or liming capacity of biochar. The basic cations, such as $\mathrm{Ca}^{2+}, \mathrm{Mg}^{2+}, \mathrm{K}^{+}$, in the form of oxides or carbonates contained in the biochars can produce $\mathrm{OH}^{-}$which in turn increase the soil $\mathrm{pH}$ and precipitated "active" $\mathrm{Al}[29,30]$. Carbonate content is responsible to the biochar alkalinity [31,32] particularly in biochars produced at high temperature [33]. The closed correlation $\left(\mathrm{r}^{2}=0.84\right)$ between alkalinity and basic cations in the biochars has also been shown by [34], and the carbonate content is closely correlated $\left(r^{2}=90\right)$ with the basic cations [30]. Soil EC was also increased with biochars and composts. Increasing soil EC could be attributed to the release of basic cations from both biochars and composts. A similar result was reported by [35].

Incorporation of biochars and composts into acid soils enhanced nutrients in the soils The increase of nutrients in soils were attributed to: (1) the release of such nutrients directly from composts and biochars (as nutrient sources); nutrients such as N, P and $\mathrm{K}$ were released by composts and some of them were released by biochars $[2,36]$; (2) soil properties changes by biochar, e.g. the increase of soil $\mathrm{pH}$ that can solubilize nutrients such as $\mathrm{P}$ or precipitated $\mathrm{Al}$ and $\mathrm{Fe}$ [30]; (3) 
adsorption of nutrients by the surface charge or the micropore structure of biochar and the complexation of $\mathrm{Al}$ and $\mathrm{Fe}$ by organic acids and functional groups of composts and biochars [37]; (4) decreasing nutrient leaching such as $\mathrm{NO}_{3}{ }^{-}$and $\mathrm{P}$ by improving water-holding capacity of the soils $[6,38,39]$, and (5) the formation of organic coating in the outer and inner pores of biochar when it was co-composted or added in combination with compost which then acted as a glue for water and nutrient retention [21,40].

The Chinese cabbage growth in the acid soils treated with biochars and composts was enhanced. The likely reasons for the increased growth especially in the Ultisol, would be the $\mathrm{pH}$ increase from 4.5 to 5.9 , decreased $\mathrm{Al}$ from $2.17 \mathrm{cmol}+/ \mathrm{kg}$ to $0.17 \mathrm{cmol}+/ \mathrm{kg}$, in addition to the release of nutrients into the soils and subsequently uptake by the plants as reported by one study [36] for ten composts. Similar result was reported by [41] who showed that application of biochar in combination with compost and low rate inorganic nitrogen fertilizer increased barley yield $54-60 \%$ compared to yield obtained from the maximum inorganic nitrogen fertilizer rate. In the second planting, the fresh and dry weights of cabbage in both soils decreased to almost $50 \%$ of the first planting (Fig. 2) perhaps due to the deficiency of nutrients such as $\mathrm{N}$ and $\mathrm{K}$. The tight linear relationship between total dry matters and $\mathrm{N}$ and $\mathrm{K}$ uptake suggested such deficiencies (Figs. 3a and 3b).

Nutrients in plant tissues, except $\mathrm{N}$ and $\mathrm{K}$ (Tables $4 \mathrm{a}$ and $4 \mathrm{~b}$ ), were in the adequate range for the normal growth of cabbage in both plantings [42]. The sufficiency of $\mathrm{P}, \mathrm{Ca}, \mathrm{Mg}, \mathrm{Fe}$, and $\mathrm{Mn}$ in cabbage plant tissues in both plantings indicated an improvement of such nutrients --supply and retention-- in these highly weathered soils by the addition of biochars and composts.

\section{Conclusions}

The nutrient retention capacity of biochars in combination with composts was assessed in two highly weathered, tropical soils of Hawai'i (Oxisol, Wahiawa series; and Ultisol, Leilehua series). The interaction between biochar and compost additions has significantly increased the $\mathrm{pH}$ of both soils, EC, P and K in the Oxisol, cabbage shoot and total fresh and dry matter in the Oxisol, plant tissue $\mathrm{Ca}$ in both soils, $\mathrm{Ca}$ and $\mathrm{Mg}$ uptake in the Oxisol, and Fe uptake in the Ultisol. Chinese cabbage growth in the Ultisol was enhanced by the addition of the lac tree wood biochar and vermicompost as a source of nutrients. Increased nutrient content in soil by compost in particular and some nutrients such as $\mathrm{Ca}$ by biochar, increased soil $\mathrm{pH}$ and decreased exchangeable $\mathrm{Al}$, and subsequently increased nutrient content in plant tissues, was likely the reasons for the better cabbage growth in the acid Ultisol. The Chinese cabbage growth in the Oxisol was also enhanced by application of biochars in combination with composts. However, there were no significant differences among the treatments with respect to the plant growth. The sufficiency of nutrients in the plant tissues, with exception of $\mathrm{N}$ and $\mathrm{K}$, for the cabbage growth in both plantings indicated an improvement of nutrients supply and retention in these highly weathered tropical soils by a combination of biochar and compost.

Author Contributions: Conceptualization-A.K.B and N.V.H; Methodology-A.K.B and N.V.H.; Software-A.K.B, N.V.H.; Validation-N.V.H, T.J.K.R. and A.A.A.; Formal Analysis-A.K.B.; Investigation-A.K.B; Resources-A.K.B., N.V.H., A.A.A.; Data Curation-A.K.B.; Writing-Original Draft Preparation-A.K.B; Writing-Review \& Editing-N.V.H., T.J.K.R., A.A.A; Funding Acquisition-N.V.H.

Funding: This research was funded by the Indonesian Higher Education Directorate General (DIKTI) overseas studies scholarship, NIFA (USDA) and Western SARE grants to Dr. Nguyen V. Hue.

Acknowledgments: Mr. X. Huang for ICP analysis

Conflicts of Interest: The authors declare no conflict of interest.

\section{References}

1. Van Meter, K. J.; Basu, N. B.; Veenstra, J. J; Burras, C. L. The nitrogen legacy: emerging evidence of nitrogen accumulation in anthropogenic landscapes. Environ. Res. Lett. 2016, 11, 1-12. 
2. Zheng, H.; Wang, Z.; Deng, X.; Zhao, J.; Luo, Y.; Novak, J.; Herbert, S.; Xing, B. Characteristics and nutrient values of biochars produced from giant reed at different temperatures. Bioresour. Technol. $2013,130,463-471$.

3. Liu, Z.; He, T.; Cao, T.; Yang, T.; Meng, J.; Chen, W. Effects of biochar application on nitrogen leaching, ammonia volatilization and nitrogen use efficiency in two distinct soils. J. Soil Sci. Plant Nutr. $2017,17,515-528$.

4. Laird, D. A.; Fleming, P.; Wang, B.; Horton, R.; Karlen, D. Biochar impact on nutrient leaching from a Midwestern agricultural soil. Geoderma 2010a, 158, 436-442.

5. Singh, B. P.; Hatton, B. J.; Singh, B.; Cowie, A. L.; Kathuria, A. Influence of biochars on nitrous oxide emission and nitrogen leaching from two contrasting soils. J. Environ. Qual. 2010, 39, 1224-1235.

6. Major, J.; Rondon, M.; Molina, D.; Riha S. J.; Lehmann, J. Nutrient leaching in a Colombian savanna Oxisol amended with biochar. J. Environ. Qual. 2012, 41,1076-1086.

7. Ventura, M.; Sorrenti, G.; Panzacchi, P.; George, E.; Tonon, G. Biochar reduces short-term nitrate leaching from A horizon in an Apple Orchard. J. Environ. Qual. 2013, 42, 76-82.

8. Liu, L.; Shen, G.; Sun, M.; Cao, X.; Shang, G.; Chen, P. Effect of biochar on nitrous oxide emission and its potential mechanisms. J. Air Waste Manage. Assoc. 2014, 64, 894-902.

9. Bai, S. H.; Reverchon, F.; Xu, C-Y.; Xu, Z.; Blumfield, T. J.; Zhao, H.; Van Zwieten L.; Wallace, H. M. Wood biochar increases nitrogen retention in field settings mainly through abiotic processes. Soil Biol. Biochem. 2015, 90, 232-240.

10. Haider, G.; Steffens, D.; Moser, G.; Müller C.; Kammann, C. I. Biochar reduced nitrate leaching and improved soil moisture content without yield improvements in a four-year field study. Agric. Ecosyst. Environ. 2017, 237, 80-94.

11. Novak, J. M.; Lima, I.; Xing, B.; Gaskin, J. M.; Steiner, C.; Das, K. C.; Ahmedna, A. M.; Rehrah, D.; Watts, D. W.; Busscher, W. J.; Schomberg, H. Characterization of designer biochar produced at different temperatures and their effects on a loamy sand. Annal. Environ. Sci. 2009, 3, 195-206.

12. Laird, D. A.; Fleming, P. D.; Davis, D. D.; Horton, R.; Wang B.; Karlen, D. L. Impact of biochar amendments on the quality of a typical Midwestern agricultural soil. Geoderma 2010b, 158, 443-449.

13. Yuan, J. H.; Xu, R. K. The amelioration effects of low temperature biochar generated from nine crop residues on an acidic Ultisol. Soil Use Manage. 2011, 27, 110-115.

14. Hossain, M. K.; Strezov, V.; Chan, K. Y.; Nelson, P. F. Agronomic properties of wastewater sludge biochar and bioavailability of metals in production of cherry tomato (Lycopersicon esculentum). Chemosphere 2010, 78, 1167-1171.

15. Silber, A.; Levkovitch, I.; Graber, E. R. pH-dependent mineral release and surface properties of corn straw biochar: agronomic implications. Environ. Sci. Technol. 2010, 44, 9318-9323.

16. Graber, E. R.; Meller-Harel, Y.; Kolton, M.; Cytryn, E.; Silber, A.; Rav David, D. Biochar impact on development and productivity of pepper and tomato grown in fertigated soilless media. Plant Soil 2010, 337, 481-496. 
17. Kolton, M.; Harel, Y. M.; Pasternak, Z.; Graber, E. R.; Elad, Y.; Cytryn, E. Impact of biochar application to soil on the root-associated bacterial community structure of fully developed greenhouse pepper plants. Appl. Environ. Microbiol. 2011, 77, 4924-4930.

18. Ding, Y.; Liu, Y. X.; Wu, W. X.; Shi, D. Z.; Yang, M.; Zhong, Z. K. Evaluation of biochar effects on nitrogen retention and leaching in multi-layered soil columns. Water Air Soil Pollut. 2010, 213, 47-55.

19. Kloss, S.; Zehetner, F.; Dellantonia, A.; Hamid, R.; Ottner, F.; Liedtke, V.; Schwanninger, M.; Gerzabek, M. H.; Soja, G. Characterization of slow pyrolysis biochars: effects of feedstocks and pyrolysis temperature on biochars properties. J. Environ. Qual. 2012, 41, 990-1000.

20. Cheng, H.; Jones, D. L.; Hill, P.; Bastami, M. S.; Tu, C. I. Influence of biochar produced from different pyrolysis temperature on nutrient retention and leaching. Arch. Agron. Soil Sci. 2017, 64, 850-859.

21. Conte, P.; Laudicina, V. A. Mechanisms of organic coating on the surface of a poplar biochar. Curr. Org. Chem. 2017, 21, 595-565.

22. Wang, Z.; Guo, H.; Shen, F.; Yang, G.; Zhang, Y.; Zeng, Y.; Wang, L.; Xiao, H.; Deng, S. Biochar produced from oak sawdust by Lanthanum (La)-involved pyrolysis for adsorption of ammonium (NH4+), nitrate (NO3-), and phosphate (PO43-). Chemosphere 2015, 119, 646-653.

23. Saleh, M. E.; Mahmoud, A. H.; Rashad, M. Peanut biochar as a stable adsorbent for removing NH4-N from wastewater: A preliminary study. Adv. Environ. Biol. 2012, 6, 2170-2176.

24. Deenik, J. L.; McClellan, M.; Uehara, G.; Antal, M. J.; Campbell, S. Charcoal volatile matter content influences plant growth and soil nitrogen transformations. Soil Sci. Soc. Am. J. 2010, 74, 1259-1270.

25. Xu, G.; Sun, J.; Shao, H. B.; Chang, S. X. Biochar had effects on phosphorus sorption and desorption in three soils with differing acidity. Ecol. Eng. 2014, 62, 54- 60.

26. Boehm, H. P. Some aspects of surface chemistry of carbon blacks and other carbons. Carbon 1994, 32, 759-769.

27. Rutherford, D. W.; Wershaw, R. L.; Reeves III, J. B. Development of acid functional groups and lactones during the thermal degradation of wood and wood components. US Geol. Surv. Sci. Investig. Rep. 2008, 2007-5013

28. Mehlich, A. Mehlich III soil test extractant: a modification of the Mehlich II extractant. Comm. Soil Sci. Plant Anal., 1984, 15, 1409-1416.

29. Smider, B.; Singh, B. Agronomic performance of a high ash biochar in two contrasting soils. Agric Ecosyst Environ. 2014, 191, 99-107.

30. Berek, A. K.; Hue, N. V. Characterization of biochars and their use as an amendment to acid soils. Soil Sci. 2016, 181, 412-426.

31. Hass, A.; Gonzalez, J. M.; Lima, I. M.; Godwin, H. W.; Halvorson, J. J.; Boyer, D. G. Chicken manure biochar as liming and nutrient spurce for acid Appalachian soil. J. Environ. Qual. 2012, 41, 1096-1106.

32. Mukome, F.N.D.; Zhang, X.; Silva, L. C. R.; Six, J.; Parikh, S. J. Use of chemical and physical characteristics to investigate trends in biochar feedstocks. J. Agric. Food Chem. 2013, 61, 2196-2204.

33. Yuan, J. H.; Xu, R. K.; Zhang, H. The forms of alkalis in the biochar produced from crop residues at different temperatures. Bioresour. Technol. 2011, 102, 3488-3497. 
34. Fidel, R. B.; Laird, D. A.; Thompson, M. L.; Lawarinenko, M. Characterization and quantification of biochar alkalinity. Chemosphere 2017, 167, 367-373.

35. Chintala, R.; Mollinedo, J.; Schumacher, T. E.; Malo, D. D.; Julson, J. L. Effect of biochars on chemical properties of acidic soil. Arch. Agron. Soil Sci. 2013, 1-12.

36. Ahmad, A.; Hue, N.; Radovich, T. Nitrogen release patterns of some locally made composts and their effects on the growth of Chinese cabbage (Brassica rapa, Chinensis group) when used as soil amendments. Compost Sci. Util. 2014, 22, 199-206.

37. Hue, N. V. Alleviating soil acidity with crop residues. Soil Sci. 2011, 176, 543-549.

38. Andrenelli, M. C.; Maienza, A.; Genesio, L.; Miglietta, F.; Pellegrini, S.; Vaccari F. P.; Vignozzi, N. Field application of pelletized biochar: Short term effect on the hydrological properties of a silty clay loam soil. Agric. Water Manag. 2016, 163, 190-196.

39. Agegnehu, G.; Srivastava, A. K.; Bird, M. I. The role of biochar and biochar-compost in improving soil quality and crop performance: a review. Appl. Soil Ecol. 2017, 119,156-170.

40. Hagemann, N.; Joseph, S.; Schmidt, H-P.; Kammann, C. I.; Harter, J.; Borch, T.; Young, R. B.; Varga, K.; Taherymoosavi, S.; Elliot, K. W.; McKenna, A.; Albu, M.; Mayrhofer, C.; Obst, M.; Conte, P.; Dieguez-Alonso, A.; Orsetti, S.; Subdiaga, E.; Behrens S.; Kappler, A. Organic coating on biochar explains its nutrient retention and stimulation of soil fertility. Nat. Cumm. 2017, 8, 1-11.

41. Agegnehu, G.; Nelson, P. N.; Bird, M. I. The effects of biochar, compost and their mixture and nitrogen fertilizer on yield and nitrogen use efficiency of barley grown on a Nitisol in the highlands of Ethiopia. Sci. Total Environ. 2016, 569-570, 869-879.

42. Uchida, R. Recommended plant tissue nutrient levels for some vegetable, fruit, and ornamental foliage and flowering plants in Hawai'i. In: Silva. J. A. and Uchida, R. (eds). Plant nutrient management in Hawai'i's soils, approaches for tropical and subtropical agriculture. CTAHR. University of Hawai'i at Manoa, Honolulu, Hawai'i, USA. 2010. Pp 57-65. 